\title{
Wojciech Sławnikowski \\ Tęsknota za ideałem. \\ Rola dzieci w filmach i filozofii twórczej Andrieja Tarkowskiego ${ }^{1}$
}

\begin{abstract}
Sławnikowski Wojciech, Tęsknota za ideałem. Rola dzieci w filmach i filozofii twórczej Andrieja Tarkowskiego [Longing for the Ideal. The Role of Children in the Films and Creative Philosophy of Andrei Tarkovsky]. „Przestrzenie Teorii” 33. Poznań 2020, Adam Mickiewicz University Press, pp. 353-383. ISSN 1644-6763. DOI 10.14746/pt.2020.33.17.
\end{abstract}

The topic of the article is the role of child characters in Andrei Tarkovsky's oeuvre. The first part concerns the early films in which children appear as main characters and represent a spiritual ideal. In the second part, later films are analysed in terms of the presence of adult characters striving for this ideal.

KEYWORDS: Andrei Tarkovsky, Russian cinema, Soviet cinema, children in film, religion in film

Andriej Tarkowski to postać, o której pamięć wciąż pozostaje żywa, choć od śmierci rosyjskiego reżysera upłynęło już ponad 30 lat. Ten wielki nowator kina, który odkrył dla jego języka nieznane wcześniej sposoby integralnego włączania snów w materię filmową i którego ostatnie filmy zapowiadają dynamicznie rozwijający się w XXI-wiecznej kinematografii nurt tzw. slow cinema, w warstwie ideowej swych dzieł pozostawał konserwatysta. Pracując w opresyjnych warunkach radzieckiej cenzury rugujaccej wszelkie przejawy niezgodnej z komunistyczną doktryną religijności, Tarkowski zdołał stworzyć własna, głęboko zakorzenioną w przedrewolucyjnej tradycji rosyjskiej filozofię. Upatrywał ratunku dla znajdującego się na skraju katastrofy świata w wierze, a jako narzędzie jej umacniania postrzegał sztukę. W ten sposób ukształtowały się ideowe podwaliny całej jego artystycznej działalności, łączące w sobie aspekty filozoficzne i teoretyczne. „Sztuka żyje i umacnia się tam, gdzie obecna jest wieczna, niezaspokojona tęsknota za duchowością i ideałem, skupiająca ludzi wokół sztuki”" - pisał. Stwierdzenie to dotyczy tak modelowych odbiorców, jak i bohaterów filmów Tarkowskiego, w których pojawianie się sztuki przeważnie wiąże się z obecnością transcendencji. Zdolność do kontemplacji

${ }^{1}$ Artykuł powstał w ramach Best Student Grantu przyznawanego przez Uniwersytet im. Adama Mickiewicza w Poznaniu.

${ }^{2}$ A. Tarkowski, Czas utrwalony, przekład, przypisy i posłowie S. Kuśmierczyk, Warszawa 2007, s. 41. 
obrazów czy poezji to tym samym otwartość na wyższe wymiary rzeczywistości. W takiej właśnie postawie widoczny jest wielce charakterystyczny dla twórczości Tarkowskiego model bohatera wyrażajacego ideał. Otwartość na transcendencję łączy się ze zdolnością do wiary, ufnościa, prostotą ducha, z dobrowolnym uniżeniem i poświęceniem, z bezwarunkową miłością i irracjonalną nadzieją na zwycięstwo dobra nad złem. Wszystkie te cechy rosyjski reżyser odnajdywał w pierwszej kolejności nie w dostojnikach kościelnych czy nawet figurach świętych, ale w dzieciach. Dlatego też filmy Tarkowskiego pełne sa postaci dziecięcych, a wielu dorosłych bohaterów stara się je naśladować, między innymi realizując model szaleńca Chrystusowego. Jest tu więc mowa o dwóch różnych grupach postaci: dzieciach sensu stricto oraz dorosłych, dla których dzieci są wzorami do naśladowania. Skoro dziecko wykazuje się idealną postawą do styczności z tym, co wedle racjonalnego światopoglądu jest niemożliwe, niewiarygodne, niesamowite, dla dorosłego staje się ono drogowskazem wiodącym w stronę duchowego ideału.

\section{Dziecko jako bohater}

W 1983 roku Tarkowski powiedział: „Dzieciństwo określa całe życie człowieka, zwłaszcza jeśli później związany jest ze sztuką" I I chociaż trzy lata później zarzekał się: „Dzieciństwo nie było nigdy tematem żadnego z moich filmów", przekonanie o kluczowym znaczeniu pierwszych lat życia łatwo można odnaleźć w twórczości rosyjskiego reżysera, zwłaszcza w najwcześniejszych dziełach, czyli w jego średniometrażowym filmie dyplomowym Walec $i$ skrzypce oraz w pełnometrażowym debiucie Dzieciństwo Iwana ${ }^{5}$. Bohaterowie tych filmów, ok. 7-letni Sasza i starszy od niego o kilka lat Iwan, zachowują tak ceniona przez Tarkowskiego perspektywę dziecka nawet wtedy, gdy zderzają się z surowym i okrutnym światem dorosłych. „Dzieciństwo zawsze jest wspaniałe. Nie sposób mówić źle o dzieciństwie, albowiem nawet najbardziej ciężkie - pozostaje w naszych wspomnieniach jako

${ }^{3}$ Un poeta nel cinema: Andrej Tarkowskij, reż. D. Baglivo (wypowiedź w filmie dokumentalnym), prod. Ciak Studio, Włochy 1983, 90 min. Na podstawie ścieżki dźwiękowej filmu oprac. i przeł. Z. Podgórzec, [w:] A. Tarkowski, Kompleks Totstoja. Myśli o życiu, sztuce i filmie, wybrał, opracował i przedmową opatrzył S. Kuśmierczyk, Warszawa 1989, s. 23.

${ }^{4}$ Pożegnanie Tarkowskiego, ,Forum” [nazwiska tłumacza nie podano] 1987, nr 7, s. 18, za: A. Tarkowski, Kompleks Totstoja..., s. 28.

${ }^{5}$ Dzieciństwo Iwana w Polsce rozprowadzano pod tytułem Dziecko wojny. Podobnie Walec i skrzypce pokazywany był jako Maty marzyciel. Za Sewerynem Kuśmierczykiem przyjmuję tłumaczenia wierniej oddające wymowę oryginalnych tytułów filmów. Por. S. Kuśmierczyk, Ksiega filmów Andrieja Tarkowskiego, Warszawa 2012, s. 456-457. 


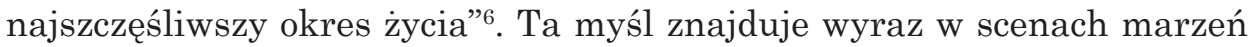
i snów bohaterów omawianych filmów. Kontrast między ideałem dzieciństwa a rzeczywistościa jest silniejszy w osadzonym w czasach wojny Dzieciństwie Iwana, jednak i w filmie dyplomowym Tarkowskiego wyraźnie się go odczuwa. Dziecko poznaje świat z właściwym sobie zdumieniem i olśnieniem, które dla wielu dorosłych są niedostępne.

Wiele jest w Walcu i skrzypcach momentów, w których dziecięca perspektywa Saszy zostaje bezpośrednio ukazana na ekranie. W drodze do szkoły ogląda on na wystawie sklepowej lustra, w których odbija się życie miasta. Dzięki operatorskim zabiegom rozsypane jabłka, przejeżdżający tramwaj i puszczona na kałuży łódka składają się na symfonię barw i kształtów, na świat przetworzony przez wyobraźnię dziecka. Również kiedy Sasza gra na skrzypcach dla Siergieja, kierowcy walca, z którym się zaprzyjaźnił, detale stają się istotne: kapiąca do kałuży woda, akustyka kamienicy, odblaski światła na ścianach. Te ostatnie pojawiają się zresztą częściej: w oknach majestatycznego gmachu odsłoniętego w czasie burzenia starych domów, w kałużach na placu, na którym Sasza i Siergiej się odnajduja, wreszcie na ścianach klatki schodowej w kończącym film marzeniu chłopca. Migotliwe światło towarzyszy więc momentom radosnym i beztroskim, w których Sasza zachwyca się światem. To właśnie w nich zdaje się leżeć owo szczęście, które Tarkowski przypisywał pierwszym latom życia każdego człowieka.

W tym kontekście szczególnie wymowna staje się sekwencja w szkole muzycznej. Sasza najpierw czeka na lekcję, okazując nieśmiałe zainteresowanie siedzącą obok koleżanka, której, wchodząc do sali, zostawia w prezencie jabłko. Podczas lekcji, gdy jego uwagę zwracaja świetlne odblaski tańczące na powierzchni wody w szklance, zaczyna gubić tempo. Nauczycielka nastawia metronom i strofuje ucznia, który salę opuszcza zasępiony i mija bez słowa ucieszoną na jego widok dziewczynkę, nie dostrzegając nawet, że ta zjadła jabłko - nacisk wywierany na chłopca przez szkołę tłumi w nim dziecięcą wrażliwość i wyobraźnię. Podobnie dzieje się w scenie z matka, która nie pozwala Saszy na wyjście z nowym przyjacielem do kina i zamyka go w pokoju na klucz.

Takiemu modelowi wychowania Tarkowski przeciwstawia postawę Siergieja, który nie stawia Saszy ograniczeń czy wymogów, a raczej stara się zachęcić go do samodzielności. Zamiast samemu stanąć w obronie dręczonego przez starszego kolegę chłopca, zachęca do tego swego małego towarzysza. Stanowczy staje się jedynie, gdy Sasza w gniewie ciska bochenkiem chleba o ziemię - wykorzystuje autorytet, aby nauczyć chłopca szacunku dla

${ }^{6}$ Un poeta nel cinema..., reż. D. Baglivo, dz. cyt., [w:] A. Tarkowski, Kompleks Totstoja..., s. 29. 
ciężkiej pracy, ale nie nadużywa go. Prezentuje postawę otwarta, opartą na wzajemnej serdeczności i przyjaźni, nie na strachu czy przymusie. Siergiej z niekłamanym podziwem przysłuchuje się grze Saszy na skrzypcach, nie chce jedynie instruować chłopca, ale i samemu się czegoś od niego nauczyć ${ }^{7}$. $\mathrm{W}$ przeciwieństwie do matki i nauczycielki, dba w pierwszej kolejności o stymulowanie potencjału chłopca, a nie zamykanie go w wyznaczanych przez metronom sztywnych ramach - zdolności małego skrzypka biora się przecież z jego wnętrza. Rezultatem jest radość Saszy grającego dla Siergieja, kontrastująca z jego przygnębieniem po lekcji.

W Walcu i skrzypcach Siergiej jest dla Saszy pomostem między krainą dziecięcych marzeń i doznań a rzeczywistością, która wymaga nauki i pracy. Tytułowemu bohaterowi Dzieciństwa Iwana takiego połaczenia brakuje - dlatego też świat tego filmu Maja Turowska nazwała słusznie w tytule swego eseju z 1962 roku „rozłamanym na dwoje”. W tekście autorka stwierdza: „Przepaść rozdziela dwie połówki tego świata: w jednej istnieje on [Iwan] jako wolna, kompletna osoba w harmonii z pięknem świata i ludzkich uczuć, podczas gdy w drugiej jest tylko narzędziem zemsty gotowym zniszczyć samego siebie dla dobra swojej misji”" Ów kontrast w filmie wyraża się w zestawieniu wojennej rzeczywistości ze snami Iwana. Wprowadzenie introspekcji było autorskim pomysłem Tarkowskiego, nieobecnym w będącym podstawą filmu opowiadaniu. Fakt ten dowodzi, że istotnie dla reżysera „wojna była niczym więcej jak nienawistnym zaburzeniem naturalnego świata dzieciństwa", świata - chciałoby się dodać - który pokazał już w swoim filmie dyplomowym. Najlepiej widać owo zaburzenie w finale Dzieciństwa Iwana, w którym radosny bieg bohatera kończy się nagłym zbliżeniem na martwe drzewo będące metaforą śmierci ${ }^{10}$. Podobną strukturę mają też inne sny w filmie: zaczynają się szczęśliwie, a kończą tragicznie, nie tylko zapowiadając śmierć chłopca, ale i ujawniając wpływ wojny na jego psychikę ${ }^{11}$. „Umysł Iwana został na zawsze ukształtowany przez nagły

${ }^{7}$ Por. M. Turovskaya, Tarkovsky. Cinema as Poetry, tłum. N. Ward, oprac. i wstęp napisał I. Christie, London 1989, s. 24-25: „Podobnie jak chłopiec intuicyjnie i bez słowa zrozumiał znaczenie pracy i wartość chleba, tak w tym momencie robotnik zaczyna pojmować wielki wysiłek i wielką siłę tkwiące w sztuce”. O ile nie zaznaczono inaczej, cytaty z książek anglojęzycznych podawane są w przekładzie autora. (Książka Mai Turowskiej w Rosji została wydana pod tytułem 7,5 ili filmy Andrieja Tarkowskogo. Dlatego też w polskich publikacjach bywa określana jako 7,5, czyli filmy Andrieja Tarkowskiego. Por. np. S. Kuśmierczyk, dz. cyt., s. 30).

${ }^{8}$ M. Turovskaya, dz. cyt., s. 7. O ile nie zaznaczono inaczej, uwagi w kwadratowych nawiasach pochodzą od autora.

${ }^{9}$ Tamże, s. 32.

${ }^{10}$ S. Kuśmierczyk, dz. cyt., s. 93.

${ }^{11}$ Tamże, s. 82. 
szok tego wyrządzonego w dzieciństwie zaburzenia, piętno przemocy, które nigdy nie zostanie zatarte" 12 .

Człowieczeństwo małego zwiadowcy stało się nawet przedmiotem najbardziej znanego sporu wokół filmu: Jean-Paul Sartre (notabene broniąc Dzieciństwa Iwana przed atakami lewicowej włoskiej krytyki) opisał bohatera jako „monstrum, [...] doskonałego potwora, [...] który objawia się tylko poprzez mordercze impulsy (np. scena z nożem), nie mogąc zerwać więzów $\mathrm{z}$ wojną i śmiercią"13. Tarkowski natomiast w wywiadzie wskazał na inną możliwą interpretację, stwierdzając: „choć nasz bohater - dziecko - pod wpływem przeżyć wojennych zdolny jest do strasznych czynów, pozostaje $\mathrm{w}$ nim ciagle jeszcze wiele człowieczeństwa" ${ }^{14}$. Wspomniana przez francuskiego filozofa scena z nożem wydaje się kluczowa dla rozstrzygnięcia tego problemu. Chłopiec ujawnia tu swą żądzę krwi i owładnięcie pragnieniem zemsty; bawić umie się już tylko w wojnę, czołga się po ziemi, udając, że tropi wroga. Nie ma tu nic z beztroskiej zabawy dziecka - słyszane przez Iwana głosy Niemców i krzyki ich przerażonych ofiar odzwierciedlają rezonujące w duszy bohatera echo krzywd i cierpień doświadczonych przez niego samego i jego najbliższych. A jednak w kluczowej chwili, gdy stoi przed zawieszonym na haku płaszczem uosabiającym w tej grze wroga, Iwan łamie się. Nie kończy wypowiadać swej groźby, tylko pada na ziemię z płaczem, „gdyż nie może zdecydować się na zadanie ostatecznego ciosu. Nie można więc mówić o nienawiści do wroga, lecz o czystości i wrodzonej dobroci dziecięcego serca"15.

Przekonanie Tarkowskiego o niewinności dziecka i jego niezdolności do kłamstwa i zła ${ }^{16}$, widoczne także w Walcu $i$ skrzypcach, jest kluczowe dla zrozumienia roli postaci dziecięcych w filmach rosyjskiego reżysera - jako ucieleśnienia ideału człowieka. Iwan, choć owładnięty nienawiścią nie jest zdolny do zabójstwa, nawet w ramach gry: naturalna, zdaniem Tarkowskiego, dobroć dziecka nadal w nim żyje. Widać to na przykład w scenie ucieczki, w której bohater zostawia jedzenie spotkanemu na pogorzelisku staruszkowi. Znamienny jest tu też prolog filmu - widz poznaje najpierw

${ }^{12}$ M. Turovskaya, dz. cyt., s. 9.

${ }^{13}$ J.-P. Sartre, Lettera su „L'Infanzia d'Ivan”, „L’Unità”, 9 X 1962, [za:] S. Kuśmierczyk, dz. cyt., s. 102. Por. też cały list Sartre'a w: Tarkovsky. Films, Stills, Polaroids \& Writings, ed. A.A. Tarkovsky, H.J. Schlegel, L. Schirmer, London 2019, s. 19-23, albo: <http://nostalghia. com/TheTopics/Sartre.html> [dostęp: 8.09.2019].

${ }^{14}$ „Dziecko wojny”: Tarkowski, rozm. Z. Pitera, „Film” 1963, nr 4, s. 13, za: A. Tarkowski, Kompleks Totstoja..., s. 206.

${ }^{15}$ Projets d'Andre Tarkowski, rozm. G. Bachkirowa, „Oeuvres et Opinions” 1963, nr 3, s. 159, za: A. Tarkowski, Kompleks Totstoja..., s. 205.

${ }^{16}$ Un poeta nel Cinema..., reż. D. Baglivo, dz. cyt., [w:] A. Tarkowski, Kompleks Totstoja..., s. 76 . 
świat szczęścia i dobroci ze snu Iwana, a dopiero później (po nagłym przebudzeniu) okrucieństwa wojny. Pojawiające się w pierwszym ujęciu filmu drzewo - ustanowione pionowa panorama kamery jako axis mundi $i^{17}$ - rymuje się z martwym drzewem z zakończenia: wojna nie wymazała do końca dziecięcej dobroci Iwana, dopiero śmierć.

Nie znaczy to jednak, że los chłopca nie jest głęboko tragiczny. Rozdźwięk między normalnym dzieciństwem (takim jak Saszy) a dzieciństwem Iwana unaoczniają relacje chłopca z oficerami. Sartre diagnozował je następująco: „dwaj oficerowie kochają go naprawdę, ale o nim samym można powiedzieć jedynie, że nie darzy ich nienawiścia”"18 a chwilę wcześniej: „Wydawałoby się, że chłopiec może [...] znaleźć wśród nich [oficerów] nowego ojca, aby zastapić tego, którego stracił. Ale jest za późno - Iwan już nie potrzebuje rodziców”19. Jest to jednak uproszczenie ze strony francuskiego filozofa. „Rozłamany na dwoje" świat Iwana dotyczy także jego relacji z oficerami - dziecko, którym wciąż do pewnego stopnia pozostał, potrzebuje bliskości i opieki; scenie powitania Iwana z kapitanem Cholinem towarzyszy wielka radość i czułość chłopca $^{20}$. Z drugiej strony, wojna zmieniła Iwana, który przedkłada teraz swoją misję nad wszystko inne, także autorytet rodziców czy oficerów. Dlatego też buntuje się przeciwko pułkownikowi Griaznowowi, gdy ten chce odesłać go do szkoły wojskowej. Ów protest kontrastuje z zachowaniem Saszy w scenie z bochenkiem chleba w Walcu i skrzypcach. Tam chłopiec postawiony wobec autorytetu starszego Siergieja szybko rozpoznał swój błąd, powściagnął gniew i wyraził skruchę - w oczach Tarkowskiego to oznaka jego dojrzałości i wrażliwości. Dla Iwana zaś najbardziej liczy się zemsta, dająca determinację do coraz to kolejnych wypraw. Niewinność i beztroska zostały mu odebrane przez wojnę, a szczęśliwy świat dzieciństwa jest już dla niego niedostępny poza tragicznie urywającymi się snami.

W zakończeniu Dzieciństwa Iwana pojawiają się sceny wycięte z radzieckich kronik filmowych przedstawiajace martwe córki Goebbelsa i dwoje innych dzieci zabitych przez ojca, oficera Luftwaffe. Tym akcentem Tarkowski rozszerza zawartą w filmie refleksję: tragiczny los Iwana wpisany zostaje w ogólniejsze „przekonanie, że na wojnie niewinni cierpią wraz z winnymi”21.

${ }^{17}$ S. Kuśmierczyk, dz. cyt., s. 84 i 94.

${ }^{18}$ Tarkovsky. Films, Stills, Polaroids \& Writings..., s. 20. Cytat w książce S. Kuśmierczyka brzmi błędnie: „dwaj oficerowie kochaja go naprawdę, ale o nim samym można tylko powiedzieć, że ich najwyżej nienawidzi”. W oryginale: ,i due ufficiali gli vogliono bene; quanto a lai, tallo ciò che si può dire, è che non li detesta" (źródło: <https://archivio.unita.news/assets/ main/1962/10/09/page_006.pdf> [dostęp: 8.09.2019]).

${ }^{19}$ Tarkovsky: Films, Stills, Polaroids \& Writings..., s. 20.

${ }^{20}$ Por. M. Le Fanu, The Cinema of Andrei Tarkovsky, BFI, London 1987, s. 22-24. Autor analizuje relację Iwana z oficerami, kładąc nacisk na motywacje tych drugich.

${ }^{21}$ Tamże, s. 30. 
Podobna sekwencja pojawi się później w Zwierciadle: archiwalne zdjęcia z czasów hiszpańskiej wojny domowej przedstawiające ewakuację dzieci do ZSRR. Wiele z nich nie wróci już nigdy do ojczyzny. „Tarkowski zdaje się dostrzegać ten rozpięty w czasie dramat w równie precyzyjny sposób, jak wspomnienia ze swojego dzieciństwa" ${ }^{22}$ czy - można by dodać - tragedię Iwana.

Już w debiucie Tarkowskiego znaleźć można dwa sposoby podkreślania przez niego duchowego ideału i cudowności dzieciństwa, do których powróci też w późniejszych dziełach. Po pierwsze, bohaterowie dziecięcy często obcują ze sztuka, w czym wyraża się ich wrażliwość na piękno, tak zewnętrzne, jak i duchowe. Idee dotyczące działalności artystycznej Tarkowski zawarł w swojej książce Czas utrwalony. Pisze tam:

W pewnym sensie każda jednostka zawsze od nowa poznaje istotę życia, sama siebie i własne dążenia. Człowiek korzysta oczywiście z doświadczeń zgromadzonych przez ludzkość, ale zdobywanie indywidualnej wiedzy etycznej i moralnej jest celem każdego ludzkiego życia z osobna i subiektywnie dokonuje się zawsze od nowa. Człowiek wciąż na nowo konfrontuje siebie ze światem, nękany dręczącym pragnieniem odzyskania i połączenia się z istniejącym poza nim ideałem, jawiącym mu się jako początek dostępny intuicyjnemu poznaniu. [...]

Człowiek, odwołując się do sztuki, przyswaja sobie rzeczywistość za pośrednictwem subiektywnych przeżyć. [...]

Pojmowanie obrazu artystycznego jest estetycznym przyjmowaniem piękna na poziomie zmysłowym, a niekiedy nawet nadzmysłowym. [...]

Sztuka nie posługuje się logiką i jest od niej niezależna, ponieważ wyraża własny postulat wiary. Obraz artystyczny może być przyjęty jedynie dzięki wierze. [...]

Można zatem mówić o analogii pomiędzy wrażeniem, które staje się udziałem przygotowanego duchowo człowieka w zetknięciu z dziełem sztuki, a doświadczeniem religijnym. Sztuka oddziałuje przede wszystkim na duszę człowieka, formując jego strukturę duchowa.

Poeta obdarzony jest wyobraźnią i psychiką dziecka. Jego sposób doznawania świata ma charakter bezpośredni, niezależnie od rangi myśli o świecie, które nim kieruja. Nie posługuje się „opisem” świata, lecz sam świat odkrywa.

Gotowość i zdolność do zaufania, zawierzenia artyście to konieczny warunek postrzegania i przyjmowania sztuki ${ }^{23}$.

Dziecko jest więc równoważnym, jeśli nie lepszym niż wielu dorosłych ludzi, odbiorca sztuki. Wynika to z jego naturalnej dla wieku ufności i spontaniczności, które pozwalaja, spojrzawszy na dzieło, intuicyjnie uchwycić i przyjąc jego esencję, kryjąca się w estetyce i przemawiająca wprost do duszy. W Ofiarowaniu Alexander, przeglądając album z ikonami, zachwyca się, poza ich mądrością i duchowościa, właśnie ową czysta, dziecięcą niewin-

${ }^{22}$ S. Kuśmierczyk, dz. cyt., s. 250.

${ }^{23}$ A. Tarkowski, Czas utrwalony..., s. 39-40 i 43-45. 
nością. Jeśli więc sztuka wyraża duchowy ideał, którego ucieleśnieniem jest dziecko, naturalnym wydaje się, że w filmach Tarkowskiego dzieci często z nią obcuja. Sasza „niewinnie i żarliwie gra na skrzypcach robotnikowi, po raz pierwszy demonstrując (zapewne ku zdumieniu ich obu) bezpośrednią siłę sztuki" ${ }^{24}$. W Zwierciadle Aleksiej ${ }^{25}$ kartkuje książkę z reprodukcjami dzieł Leonarda da Vinci, o której wpływie na rozwój jego wrażliwości Turowska pisze: „sztuka wkracza w życie Aleksieja poprzez opasły przedrewolucyjny tom poświęcony Leonardowi da Vinci [...]. Wpływa ona na jego podatną duszę i przekształca świat wspomnień tak, że Sołowiowa, żona doktora, i wszystkie detale wygodnego, nieznającego głodu życia, które wiedzie ona pomimo wojny - włączając w to jej dziecko, owiniętego w koronki cherubinka - niespodziewanie nabieraja kolorów i tekstur rodem ze złotego okresu renesansu" ${ }^{26}$. Odwrotny wpływ widać w scenie z Dzieciństwa Iwana, w której oglądający rycinę Dürera bohater w jednym z jeźdźców Apokalipsy rozpoznaje „szwaba”, którego widział na motocyklu. Koszmarna rzeczywistość przesłania mu piękno dzieła i odbiera zdolność jego kontemplacji.

Poza muzyką i malarstwem Tarkowski otacza swoich dziecięcych bohaterów także i dziełami sztuki słowa. Martyszka, córka Stalkera, w ostatniej scenie filmu czyta wiersz Fiodora Tiutczewa Lubie oczęta twe, kochanie... (Люблю глаза твои, мой друг...). Ponownie można tu przywołać celną uwagę Mai Turowskiej: „Dla mnie iskierką nadziei w tej małej kalekiej dziewczynce nie są ani jej zdolności telekinetyczne, ani nawet wysoki poziom rozwoju duchowego, dzięki któremu wybiera jako swoją lekturę Tiutczewa, lecz prostota, z którą wypowiada słowa będące poza zasięgiem starszych od niej bohaterów"27. Osnuty wokół subtelnych obserwacji emocji i zachowań wiersz dziewczynka wygłasza spokojnie i z doskonałym wyczuciem rytmu; nie czyta, lecz powtarza słowa już po opuszczeniu książki. Po raz kolejny dziecięca bezpośredniość okazuje się zatem atutem, bo przecież - jak mówi w Nostalgii Domenico - „życie jest proste”.

W mniej jednoznaczny, ale również doniosły kontakt ze sztuką wchodzi w Ofiarowaniu Malec. Za namową ojca pielęgnuje zasadzone na brzegu morza suche drzewo (określone przez Alexandra na początku filmu jako ,ikebana”, które w zakończeniu rozkwita „złotym blaskiem odbijających się od powierzchni wody promieni słońca"28. W tej samej scenie chłopiec, milczący

${ }^{24}$ M. Le Fanu, dz. cyt., s. 18.

${ }^{25} \mathrm{~W}$ tej scenie Zwierciadta szczególnie trudne jest rozpoznanie, który z bohaterów granych przez Ignata Danielcewa pojawia się na ekranie. Za Mają Turowską przyjmuję, że jest to Aleksiej.

${ }^{26}$ M. Turovskaya, dz. cyt., s. 67.

${ }^{27}$ Tamże, s. 114-115.

${ }^{28}$ S. Kuśmierczyk, dz. cyt., s. 411. 
przez cały film ze względu na niedawną operację migdałków, po raz pierwszy przemawia: „Na początku było Słowo. Dlaczego, tato?” - pyta, odwołując się do wcześniejszych słów Alexandra. Zakończenie filmu, nazywanego czasem „testamentem” Tarkowskiego ${ }^{29}$, przynosi więc nadzieję na przetrwanie ludzkości. Mozolne nauki Alexandra nie były nadaremne, gdyż pobudzają Malca do refleksji i do rozwoju duchowego - drzewo rozkwitło. Efekt jest tu podobny do tego, jaki kontakt ze sztuką wywierał na innych dziecięcych bohaterów Tarkowskiego. A jeśli wziąć pod uwagę kończąca film dedykację dla syna reżysera, w zakończeniu Ofiarowania można dostrzec też osobistą nadzieję na przydatność wyrażanego poprzez swoją sztukę posłannictwa.

Refleksja nad ostatnią scena w całej filmografii Tarkowskiego prowadzi też do drugiego stosowanego przez niego sposobu na zaznaczenie wyjątkowego duchowego statusu dzieci, którym jest udział tych bohaterów w cudownych bądź mistycznych scenach. Sean Martin słusznie zauważa, że niewytłumaczalne w racjonalny sposób wydarzenia intensyfikują się w późnej twórczości rosyjskiego reżysera ${ }^{30}$, są więc i takie sceny (jak na przykład lewitacja w Zwierciadle i Ofiarowaniu), w których „cuda” odbywaja się bez udziału dzieci. Nie zmienia to jednak faktu, że każda, z wyłączeniem Saszy, postać dziecięca będąca w kontakcie ze sztuką doznaje też swego rodzaju ponadnaturalnego doświadczenia; stawia to dzieci w centrum tego magicznego świata, w którym możliwe sa zjawiska naukowo niewytłumaczalne. W Dzieciństwie Iwana jest to lot głównego bohatera w pierwszej scenie fil$\mathrm{mu}$ - zdarzenie o tyle prozaiczne, że umieszczone w świecie snu i w związku z tym łatwe do zinterpretowania jako sposób ukazania szczęścia bohatera ${ }^{31}$. Znacznie bardziej tajemnicze sa epizody ze Zwierciadła i Stalkera, które jako odbywające się na jawie - podważaja poczynione przez widza założenia na temat ontologii świata przedstawionego. Ignat, pozostawiony sam w mieszkaniu ojca, spotyka tam niespodziewanie nieznaną kobietę, która prosi go o odczytanie listu Puszkina. Siedzi ona w pokoju, który jeszcze przed chwilą (na początku ujęcia) był pusty. Znika zresztą równie nagle, jak się pojawiła: Ignat idzie otworzyć drzwi staruszce, która pomyliła numery domów, a gdy wraca do pokoju, na stole pozostaje tylko szybko znikający ślad po filiżance tajemniczej kobiety. Wiele miejsca można by poświęcić na analizy i dywagacje dotyczące tożsamości i roli tej bohaterki w filmie (wystarczy nadmienić, że pojawia się ona ponownie w scenie śmierci narrato-

${ }^{29}$ Por. np. czwartą stronę okładki książki L. Alexander-Garrett Andrei Tarkovsky: The Collector of Dreams, tłum. M. Amadei Ashot, London 2013: „Ofiarowanie to ostatnie arcydzieło Andrieja Tarkowskiego. Film nakręcono w Szwecji, latem 1985 roku. Okazał się być ostatecznym testamentem reżysera".

${ }^{30}$ S. Martin, Andrei Tarkovsky, Harpenden 2011, s. 150.

${ }^{31}$ S. Kuśmierczyk, dz. cyt., s. 84. 
ra, aby złożoność problemu stała się wyraźna). Tutaj jednak ważniejszy od intencji reżysera ${ }^{32}$ jest sam charakter obecności postaci w filmie. Seweryn Kuśmierczyk przeprowadza dogłębną analizę muzyki w opisywanej scenie, wskazując na tworzoną przez nią ramę, i konkluduje: „Rozmowa chłopca z nieznajomą otrzymuje dzięki temu autonomię i wykracza poza linearność czasu" ${ }^{33}$. Ignat między wyjśsiem matki z mieszkania a rozmową telefoniczną z ojcem doświadcza więc wizji bądź wizyty rodem z innego świata, wchodzi w kontakt z transcendencja. Kuśmierczyk pisze dalej o tajemniczej kobiecie: „Jej prośba sprawia, że głośno odczytywane słowa Puszkina, bijący z nich sens dotyczący roli i znaczenia Rosji, zamieniają tę scenę w szczególną lekcje patriotyzmu" 34 - jak gdyby duch czuwał nad rozwojem chłopca. Świat przedstawiony otwiera się $\mathrm{w}$ tej scenie na tajemnicze przestrzenie niedostępne konwencjonalnemu poznaniu, czego katalizatorem zdaje się Ignat.

W Stalkerze związek dziecka ze sferą nadprzyrodzona jest bardziej bezpośredni, choć równie zagadkowy. W ostatniej scenie filmu Martyszka przesuwa naczynia po stole za pomoca telekinezy. W typowy dla Tarkowskiego sposób zdarzenie to wymyka się jednoznacznej interpretacji. Sam twórca powiedział w wywiadzie: „Tajemnicze umiejętności dziecka to prawdopodobnie symboliczne wyobrażenie jakiejś perspektywy, nowych, nie znanych nam jeszcze sił należących do sfery duchowej i świata materialnego jednocześnie" ${ }^{35}$. Kontakt z nimi, podobnie jak w Zwierciadle, następuje za pośrednictwem dziecka. Inaczej tę scenę odczytuje Rafał Rutkowski: „Szklanki, które w zakończeniu filmu "same» przesuwają się po stole, są symbolem cudów, których potrafi dokonać dziecko" ${ }^{36}$. W postaciach Ignata i Martyszki Tarkowski akcentuje więc szczególną bliskość dzieci - jako istot czystych duchowo - do transcendencji. Wreszcie, w zakończeniu Ofiarowania znaleźć można jeszcze inną zależność między dzieckiem a cudem. Brak tu zjawisk nadprzyrodzonych (rozkwitnięcie martwego drzewa następuje bowiem symbolicznie poprzez sfilmowanie suchych gałęzi na tle skrzącego się morza). Jednak sensem ofiary Alexandra jest właśnie cud: przetrwanie Malca i reszty rodziny oraz, pośrednio, uchronienie ludzkości przed duchową zagłada. „Chłopiec jest feniksem powstającym z popiołów ze stosu pogrzebo-

${ }^{32}$ Por. rozważania na ich temat: M. Turovskaya, dz. cyt., s. 90, i S. Kuśmierczyk, dz. cyt., s. 255.

${ }^{33}$ S. Kuśmierczyk, dz. cyt., s. 276 (przyp. 133).

${ }^{34}$ Tamże, s. 255.

${ }^{35}$ A. Tassone, Entretien avec Andrei Tarkowski (sur „Stalker”), „Positif” nr 247, X 1981, s. 25, przeł. Z. Kwiatkowski, za: A. Tarkowski, Kompleks Totstoja..., s. 266-267.

${ }^{36}$ R. Rutkowski, Stańcie się jak dzieci! O twórczości filmowej Andrieja Tarkowskiego, „Znak” 2007, nr 621, <http://www.miesiecznik.znak.com.pl/6212007rafal-rutkowskistancie-sie-jak-dzieci-o-tworczosci-filmowej-andrieja-tarkowskiego/> [dostęp: 11.09.2019]. 
wego swego ojca" ${ }^{37}$ - stwierdza Jeremy Mark Robinson. To metafora równie górnolotna, co trafna. Dziecko, które dzięki poświęceniu rodzica zaczyna pielęgnować w sobie duchowy ideał, samo w sobie jest tu cudem.

Na koniec części poświęconej dzieciom sensu stricto warto powiedzieć kilka słów o bohaterach znajdujących się na granicy dzieciństwa i dorosłości. Do tej grupy zaliczyć można przede wszystkim Maszę i porucznika Galcewa z Dzieciństwa Iwana oraz Boryskę i Fomę z Andrieja Rublowa. Łączy ich wiek: wszyscy mają kilkanaście bądź dwadzieścia kilka lat. Różni - stosunek do ideału dzieciństwa. Masza duchowo pozostaje dzieckiem: jest naiwna, bezbronna, ufna ${ }^{38}$. Choć w relacji z Cholinem jest początkowo ostrożna i nieśmiała, niemal oporna, po czasie odkrywa w sobie nowe uczucia, których wyrazem jest scena „tańca brzóz”. Wyraża ona szczęście bohaterki, na które podczas wojny nie ma miejsca. Scena kończy się, podobnie jak sny, katastroficznym akcentem: obrazem dwóch powieszonych przez Niemców zwiadowców. Masza jest więc postacią na swój sposób analogiczną do Iwana, a jej obecność w filmie podkreśla tragiczny wpływ wojny na duchowość człowieka ${ }^{39}$. Porucznik Galcew jest z kolei wyraźnie skontrastowany z głównym bohaterem filmu. To prosty żołnierz, dla którego udział $\mathrm{w}$ wojnie to obowiazek i praca, a nie - jak w przypadku Iwana - wendetta ${ }^{40}$. Jest dobroduszny i wrażliwy, ale jednocześnie nauczył się już funkcjonowania w świecie dorosłych.

Bohater, którego położenie na granicy dzieciństwa i dorosłości jest najbardziej ambiwalentne to Boryska. Już jego wiek jest trudny do ustalenia. Mark Le Fanu określa go na około 14 lat, Rafał Rutkowski nazywa go wprost dzieckiem; wcielający się w tę rolę Nikołaj Burlajew w czasie zdjęć był w wieku 18-19 lat ${ }^{41}$. Dokładny wiek bohatera jest jednak mniej ważny niż interpretacja tej postaci i jej działań - a na tym polu również pojawiają się bardzo rozbieżne głosy. Zarówno Maja Turowska, jak i noblista Aleksandr Sołżenicyn dostrzegli w Borysce „ukształtowany w latach 30. typ stalinowskiego bohatera pracy socjalistycznej: niedouczonego, krzyczącego na innych, lekceważącego zasady rzemiosła" ${ }^{42}$, zwracając też uwagę na oszu-

${ }^{37}$ J.M. Robinson, The Sacred Cinema of Andrei Tarkovsky, Maidstone 2006, s. 519.

${ }^{38}$ Tarkowski znacząco odszedł od wyglądu bohaterki w pierwowzorze literackim, aby osiagnąc ten efekt. Por. A. Tarkowski, Czas utrwalony..., s. 35 i S. Kuśmierczyk, dz. cyt., s. 95-96.

${ }^{39}$ Por. S. Kuśmierczyk, dz. cyt., s. 95, oraz M. Turovskaya, dz. cyt., s. 7.

${ }^{40}$ M. Turovskaya, dz. cyt., s. 6.

${ }^{41}$ Aktor urodził się 3 lipca 1946 roku (źródło: Encyklopedia PWN, <https://encyklopedia. pwn.pl/haslo/Burlajew-Nikolaj-P;3882140.html>, dostęp: 12.09.2019). Pierwsze zdjęcia nakręcono w kwietniu 1965 roku. Film został przyjęty przez Goskino w lipcu 1966 roku (źródło: S. Kuśmierczyk, dz. cyt., s. 112-113).

${ }^{42}$ S. Kuśmierczyk, dz. cyt., s. $130-131$. 
stwo, którego się dopuścił (kłamiąc żołnierzom księcia na temat rzekomo posiadanego przezeń sekretu odlewania dzwonów tylko po to, aby zabrali go z wymarłej wioski). Taka interpretacja kłóci się z wymową całego filmu. Boryska to postać kluczowa dla przemiany, która przechodzi Rublow: ikonopis łamie wieloletni ślub milczenia, poruszony determinacją młodego ludwisarza. „Boryska siłą swojej wiary, swym przekonaniem i przejęciem, jakie wkłada w odlewanie dzwonu, budzi Andrieja z milczenia"43. Jego zdolność do tej wiary w pochodzacy od Boga talent zbliża go do duchowego ideału ucieleśnianego przez dziecko. Za problematyczną w takiej interpretacji kwestię można uznać kłamstwo bohatera, które świadczy z jego strony o kalkulacji - w postrzeganiu Tarkowskiego obcej dzieciom ${ }^{44}$. Intencją Boryski w równej mierze, co chęć ucieczki z wioski, jest tu jednak wewnętrzna potrzeba tworzenia, pragnienie podążania za swym powołaniem. Czy to pobudka dość szlachetna, by usprawiedliwić oszustwo - każdy widz musi zdecydować $\mathrm{sam}^{45}$. W tym samym filmie pojawia się też drugi nastoletni artysta: uczeń Rublowa Foma. Również w tej postaci łączą się cechy dziecka i dorosłego: w noweli Sad Ostateczny. 1408 r. buńczuczny chłopak odchodzi od swego mistrza, zniecierpliwiony opóźnieniem w malowaniu katedry; później, w noweli Najazd. 1408 r., ginie od strzały Tatara, zmieniając się $\mathrm{w}$ anioła ${ }^{46}$. Z jednej strony jest więc butny, $\mathrm{z}$ drugiej - $\mathrm{w}$ chwili śmierci przechodzi w sferę transcendencji. Ponadto, tak u terminującego u Rublo-

${ }^{43}$ „Strasti po Andrieju”, rozm. A. Lipikow (wywiad przeprowadzony 1 lutego 1967 roku), „Litieraturnoje Obozrienje” 1988, nr 9, s. 76, przeł. S. Kuśmierczyk, za: A. Tarkowski, Kompleks Totstoja..., s. 217.

Peter Green opisuje przemianę Rublowa przy użyciu tej samej metafory, z której w kontekście zakończenia Ofiarowania skorzystał J.M. Robinson: „Dzwon Boryski, podobnie jak motyw dzwonu w Dzieciństwie Iwana, jest oznaka triumfu wiary - tu wiary artysty w ideę i w samego siebie (a ostatecznie także i w Boga) - która budzi się w Rublowie jak feniks z popiołów". Ta przypadkowa zbieżność sformułowań obu badaczy pokazuje, że motyw odrodzenia i odnowy obecny był zarówno w tak wczesnym dziele, jak Andriej Rublow, jak i w ostatnim filmie reżysera. Cyt.: P. Green, Andrei Tarkovsky: The Winding Quest, London 1993, s. 49. Na temat dzwonu w Dzieciństwie Iwana zob. tamże, s. 32.

${ }^{44}$ Por. Un poeta nel cinema, reż. D. Baglivo, dz. cyt., [w:] A. Tarkowski, Kompleks Totstoja..., s. 76: „Dzieci i zwierzęta są niewinne. [...] Nie potrafią kłamać, są szczere z samej swojej natury, samej swojej istoty. Zaś człowiek dorastając, [...] stopniowo uczy się kłamać".

${ }^{45}$ Por. też bardzo interesująca interpretację postaci Boryski i Rublowa jako dwóch oblicz Tarkowskiego jako artysty w: V.T. Johnson, G. Petrie, The Films of Andrei Tarkovsky. A Visual Fugue, Bloomington 1994, s. 90-91.

${ }^{46}$ Taką interpretację sceny śmierci Fomy sformułował Seweryn Kuśmierczyk. Zawarty w scenie błąd montażowy badacz odczytuje jako celowy zabieg tworzący dysonans i zwracający uwagę na tkwiącą w plecach chłopca strzałę, której ułożenie przypomina znane z wyobrażeń ikonograficznych skrzydła aniołów. Upadając do rzeki, Foma czyni ręką znak krzyża oraz rozbryzguje wodę, której krople zdają się osiadać na obiektywie kamery i zacierać ostrość obrazu, wzmacniając wyraz sceny. Por. S. Kuśmierczyk, dz. cyt., s. 151-153. 
wa Fomy, jak i u pozostałych nastoletnich bohaterów obecny jest czynnik styczności ze sztuką: Boryska sam jest artystą, Galcew ogląda z Iwanem ryciny Dürera, wykazując się większą wrażliwością niż mały zwiadowca, a Masza dyskutuje z Cholinem o literaturze, opowiadając, jak kiedyś spotkała na żywo znanych pisarzy.

W przypadku Boryski i Maszy można też wskazać na doświadczane przez nich momenty epifanii. Sa one pokrewne z opisanymi wyżej cudami towarzyszącymi dzieciom, ale w przeciwieństwie do telekinezy czy pojawiającej się znikąd kobiety, nie są to zdarzenia paranormalne. Masza pod wpływem ogarniającej ją radości ze spotkania z Cholinem (która ogarnia ja powoli, w miarę ustępowania oszołomienia) biegnie przez las, co w warstwie formalnej zostaje oddane poprzez nawiąujący do filmu Leca żurawie „taniec brzóz" 47 . Z kolei Boryska podczas kopania dołu do odlania dzwonu natrafia na korzeń, który okazuje się należeć do rosnącego nieopodal dużego drzewa. Kamera unosi się i pokazuje oniemiałego nagłym odkryciem chłopca z góry, wewnątrz wyznaczanego przez dół koła. Drzewo jest tutaj, jak pisze Dmitrij Sałynski, arbor mundi - „drzewem kosmicznym”48 - a zachwyt bohatera to wynik odczutej przez niego w tej chwili więzi ze światem. Wydarzenia epifanijne dodatkowo podkreślają bliskość tych dwojga postaci do dziecięcego ideału.

Spoglądając na bohaterów na granicy dzieciństwa i dorosłości, można dostrzec, że wszyscy troje pojawiaja się we wczesnych dziełach Tarkowskiego. Faktycznie, w późniejszych filmach wśród ważnych bohaterów nie ma żadnych nastolatków, a jedynie albo ludzie dorośli, albo dzieci przed okresem dojrzewania, dzięki czemu uwydatniona zostaje różnica między naturalnie realizującymi ideał dziećmi a dążącymi do niego dorosłymi. Jest to symptom ważnego przejścia, które nastapiło w twórczości rosyjskiego reżysera od podejmowania tematyki dzieciństwa w sensie biologicznym do dzieciństwa duchowego.

\section{Dziecko jako wzór}

Postawa dziecka i wyrażany przez nią duchowy ideał objawiają się także w rozterkach i działaniach wielu dorosłych bohaterów Tarkowskiego. Do opisania sposobów, w jakie realizują oni ten model można użyć wielu metod i odwołać się do różnych kontekstów. Niewątpliwie jednym z ważniejszych jest reprezentowany przez wielu bohaterów typ postaci, którym jest sza-

${ }^{47}$ Tamże, s. 97-98.

${ }^{48}$ D. Sałynski, Kanon Tarkowskiego, tłum. I.A. NDiaye, [w:] Strefa filmu. Kino Andrieja Tarkowskiego, red. I.A. NDiaye, M. Sokołowski, Torun 2013, s. 194. 
leniec Chrystusowy (ros. юродивый, stąd w jęz. polskim także jako „jurodiwyj" ${ }^{49}$ ). To figura obecna w kulturze europejskiej w różnych przejawach i odmianach, a wywodząca się z Pierwszego Listu św. Pawła do Koryntian i zawartej w nim idei „głupoty dla Chrystusa” ${ }^{50}$. W dawnej Rusi jurodstwo przeżywało rozkwit od XV do pierwszej połowy XVII wieku ${ }^{51}$, po czym zostało wskrzeszone w literackiej formie przez Fiodora Dostojewskiego w powieści Idiota $^{52}$, której bohater, książę Myszkin, jest nowoczesną wersją szaleńca Chrystusowego: Dostojewski odszedł w jego kreacji od hagiograficznego kanonu i inspirował się między innymi postacią Don Kichota ${ }^{53}$. Za podstawową funkcję jurodiwego, tak tradycyjnego, jak i ,zmodernizowanego”, uznaje się funkcję krytyczną wobec społeczeństwa i jego norm. Tarkowski pozostając pod silnym wpływem Dostojewskiego, przejął figurę szaleńca Chrystusowego i wykorzystał wielokrotnie w swej twórczości.

Święty głupiec reprezentuje w jego filmach sferę duchową i proponuje transcendentalną perspektywę spojrzenia na ludzkie sprawy. W tym sensie, irracjonalna prawda i ,amoralność” szaleńca są wyniesione wyżej niż racjonalizm i świecka moralność, które, według niego [Tarkowskiego], doprowadzą ostatecznie do katastrofy i zniszczenia ludzkiej cywilizacji. Święty głupiec [...] był dla Tarkowskiego ostatnim bastionem wiary: reprezentacją tego, ,czego brakuje w świecie: wewnętrznej wolności i wiary, dla których nie ma rzeczy niemożliwych" ${ }^{\text {"4 }}$.

Działalność szaleńców Chrystusowych wynikała więc z wewnętrznego imperatywu o podłożu religijnym i charakteryzowała się przede wszystkim bierną bądź czynną opozycją wobec zasad społecznych. Seweryn Kuśmierczyk wskazuje ponadto, że w potocznym rozumieniu jurodstwo często wiązano z szaleństwem. Badacz wyjaśnia, że w tradycji prawosławnej istniały dwa rodzaje jurodstwa: organiczne (oznaczające upośledzenie umysłowe) oraz dobrowolne (podejmowane świadomie, często przez ludzi wykształconych) ${ }^{55}$.

${ }^{49}$ Por. Stownik języka polskiego PWN, <https://sjp.pwn.pl/slowniki/jurodiwyj.html> [dostęp: 13.09.2019]. S. Kuśmierczyk używa spolszczonej formy ,jurodiwy”. W języku angielskim funkcjonuje pojęcie „the holy fool”, które można przetłumaczyć jako „święty głupiec”.

${ }^{50}$ Por. 1 Kor 4,10: „my głupi dla Chrystusa, wy mądrzy w Chrystusie, my niemocni, wy mocni; wy doznajecie szacunku, a my wzgardy" (źródło: <https://biblia.deon.pl/rozdzial.php?id=289>, dostęp: 13.09.2019). Wnikliwą analizę biblijnego rodowodu szaleńca Chrystusowego daje Alina G. Birzache: A.G. Birzache, The Holy Fool in European Cinema, Abingdon 2016, s. 20-26.

${ }^{51}$ S. Kuśmierczyk, dz. cyt., s. 295.

${ }^{52} \mathrm{Na}$ fali trwającego od połowy XIX wieku wzrastającego zainteresowania kultura staroruska. Por. szczegóły w: S. Kuśmierczyk, dz. cyt., s. 297.

${ }^{53}$ A.G. Birzache, dz. cyt., s. 39.

${ }^{54}$ Tamże, s. 81-82. Użyty przez autorkę cytat pochodzi z: B.A. Kovàcs, A. Szilàgyi, Les mondes d'Andrei Tarkowski, traduit du hongrois par V. Charaire, L'Age d'Homme, Lausanne 1987 , s. 157.

${ }^{55}$ S. Kuśmierczyk, dz. cyt., s. 295-296. 
O podobnym podziale mówi też Alina G. Birzache, odnosząc go jednocześnie do sposobów przedstawiania szaleńców Chrystusowych w kinematografii:

Peter C. Bouteneff zaproponował przydatny podział postaci hagiograficznego świętego głupca na trzy typy: szokujacy psotnik, „przerażający asceta” i błogosławiony idiota. W kinie [...] podział ten rozgałęził się w dwie strony: zgłębiane są możliwości, jakie dają postaci błogosławionego idioty oraz świętego szaleńca, w którym zawieraja się dwa pozostałe typy. Błogosławiony idiota po rosyjsku byłby określony jako „błażenny” (błogosławiony, niewinny), a jego bądź jej głupota objawiałaby się jako „intelektualna i fizyczna prostota i pospolitość”. Podczas gdy zachowanie świętego szaleńca jest jawnie, często agresywnie prowokujace, błogosławiony idiota jest łagodny i mniej aktywny w wyrażaniu własnych opinii od swego odpowiednika ${ }^{56}$.

Widoczny jest tu wyraźny związek postaci szaleńca Chrystusowego z utożsamianym w twórczości Tarkowskiego przez dzieci ideałem prostoty i ufności. Błogosławiony idiota to właśnie osoba dorosła, która w naturalny sposób zachowuje się niczym dziecko. W przypadku świętego szaleńca takie postępowanie jest wynikiem wyboru podyktowanego niezachwiana wiara oraz poszukiwaniem wewnętrznej wolności i wiąże się z otwartą krytyką zastanej rzeczywistości. Inny sposób prezentacji tego podziału to wyróżnienie pasywnego i aktywnego świętego głupca. Oba typy szaleńca Chrystusowego obecne są w twórczości Tarkowskiego, przy czym wielu bohaterów nie wpisuje się w nie w sposób jednoznaczny.

Rafał Rutkowski dokonuje jeszcze innego podziału dorosłych postaci z filmów rosyjskiego reżysera. Kryterium jest tutaj przede wszystkim ich stosunek do „duchowego dziecięctwa”, a więc stanu właściwego szaleńcom Chrystusowym, który dla Rutkowskiego jest tożsamy z ewangelicznym ideałem wiary, nadziei i miłości. Cztery wyróżnione w tym ujęciu grupy postaci to ${ }^{57}$ :

1. Bohaterowie dalecy od ideału: „Egoiści ulegający różnego rodzaju grzesznym żądzom i namiętnościom, targani sprzecznymi uczuciami, małostkowi, którzy nie potrafią zrozumieć ani świata, ani samych siebie. [...] Żadne z nich nie wierzy w Boga i nie potrafi się modlić". Do tej grupy należą (wg Rutkowskiego): Pisarz i Profesor ze Stalkera, Eugenia z Nostalgii oraz Adelajda i Victor z Ofiarowania.

${ }^{56}$ A.G. Birzache, dz. cyt., s. 54-55. Użyty przez autorkę cytat pochodzi z: P.C. Bouteneff, “'What Kind of Fool Am I?', Further Gleanings from Holy Folly”, [w:] Abba: the Tradition of Orthodoxy in the West, festschrift for Bishop Kallistos (Ware) of Diokleia, ed. J. Behr, A. Louth and D. Conomos, Crestwood 2003, s. 344.

${ }^{57}$ Podaję w zmienionej względem pierwowzoru kolejności, aby oddać powolne zbliżanie się do ideału. U Rutkowskiego kolejność grup jest następująca (używając przyjętej przeze mnie numeracji): 1, 4, 3, 2. Wszystkie cytaty w punktach 1-4 pochodzą z: R. Rutkowski, dz. cyt. 
2. Bohaterowie w drodze do ideału: „Bohaterowie ci przeżywają religijny i moralny kryzys - [...] nie potrafią się jednak pogodzić z własną duchową kondycją i podejmują działania zmierzajace do odzyskania utraconej wiary, nadziei i miłości. Osoby te dopiero rozpoczynają wewnętrzną walkę ze złem, z samymi sobą. Dopiero zaczynają uniżać się przed Bogiem, zdobywać mądrość i stawać «jak dzieci»”. Do tej grupy Rutkowski przyporządkowuje: Aleksieja ze Zwierciadta, Gorczakowa z Nostalgii oraz Aleksandra z Ofiarowania.

3. Bohaterowie, którzy osiagnęli ideał: „duchowe dziecięctwo nie zostało im dane. Musieli je w sobie wypracować. Bohaterowie ci uniżyli się przed Bogiem i stali «jak dzieci» dzięki wewnętrznemu wysiłkowi, duchowej pracy, którą wykonali nad sobą". Do tej grupy należą: Rublow, Stalker oraz Domenico z Nostalgii.

4. Bohaterowie, którzy zawsze żyli zgodnie z ideałem: „ludzie ci przypominają dzieci i/lub potrafiąjak dzieci kochać i ufać”. „O wszystkich tych osobach [...] chciałoby się rzec [...] że są one, i zawsze były, «jak dzieci»”. W tej grupie znajdują się: Siergiej z Walca i skrzypiec, Masza z Dzieciństwa Iwana, „Błażenna” z Andrieja Rublowa ${ }^{58}$, Żona ze Stalkera oraz Maria i Julia z Ofiarowania ${ }^{59}$.

Takie zestawienie, przy całej swojej schematyczności i potencjale do generowania sporów o umiejscowienie konkretnych postaci, dobrze obrazuje różnorodność postaw przyjmowanych przez bohaterów Tarkowskiego. Wyraźnie widać też, że typ błogosławionego idioty z podziału Birzache odpowiada dość ściśle ostatniej z grup (na poziomie definicji). Z kolei świętym szaleńcem można by nazwać niektórych bohaterów z grup drugiej i trzeciej. Ponadto, Rutkowski podkreśla przynależność przedstawicieli pierwszych trzech grup do intelektualnej elity, co pozwala na zestawienie jego podziału z opisanymi przez Kuśmierczyka dwoma odmianami jurodstwa. Jak widać, przywoływane i dokonywane przez uczonych klasyfikacje ujmują problematykę szaleńców Chrystusowych i ich odpowiedników wśród bohaterów Tarkowskiego z różnych stron, częściowo się pokrywając, a częściowo znosząc. Kuśmierczyk zwraca szczególną uwagę na zdrowie psychiczne jurodiwych oraz na poziom ich wykształcenia. Birzache z kolei skupia się na funkcji krytycznej świętego głupca, wskazując na jego bierną bądź czynną postawę względem społeczeństwa. Wreszcie Rutkowski przygląda się wewnętrznym przemianom bohaterów i ich drodze ku osiagnnięciu ewangelicznego ideału wiary, nadziei i miłości. Analizy te pokazuja, że obecność szaleńców Chrystusowych i postaci im pokrewnych w twórczości Tarkowskiego jest złożona, ale zarazem niezwykle ważna dla wyrażanego poprzez filmy światopoglądu rosyjskiego reżysera.

\footnotetext{
${ }_{58}$ Por. przyp. 71.

${ }^{59}$ R. Rutkowski, dz. cyt.
} 
W 1993 roku Peter Green we wstępie do swej książki Andrei Tarkovsky: The Winding Quest wystapił w obronie Tarkowskiego przed krytycznymi opiniami, w których jego twórczość deprecjonowano jako „walczący irracjonalizm”. Green argumentował, że „pomimo metafizycznego wymiaru jego dzieła i pomimo faktu, że ostatecznym tematem i źródłem inspiracji była dla Tarkowskiego jego wiara, skrupulatnie dążył on do przestrzegania fizycznych praw świata" ${ }^{\prime 0}$. Badacz wskazuje, że elementy nadprzyrodzone, niewytłumaczalne, parapsychologiczne itp. zawsze są u Tarkowskiego dwuznaczne. Dzieje się tak poprzez umieszczenie ich w świecie snów (często w nieoczywisty sposób, tak, że nie wiadomo, co jest jawa, a co snem ${ }^{61}$ ) albo zakwestionowanie ich przez samych bohaterów (na przykład w scenie ze Stalkera, w której tajemniczy głos zatrzymuje Pisarza) ${ }^{62}$. Stąd Green wyprowadzał wnioski dotyczące charakteru przeprowadzanej przez rosyjskiego reżysera krytyki współczesnej cywilizacji:

Wykorzystanie przez Tarkowskiego elementów nadprzyrodzonych i mistycznych nie powinno wydawać się ucieczką od racjonalizmu, a raczej częścią dokonywanej przez niego próby przywrócenia równowagi pomiędzy światem materialnym i duchowym. Opisał on dewaluację słów, obserwując, jak współczesny człowiek jest przytłoczony informacja, jak wiadomości mogące zmienić jego życie nie docierają do niego, jak nie jest już otwarty na możliwe cuda ${ }^{63}$.

Odpowiedzią Tarkowskiego na diagnozowany przezeń zanik duchowości (mający w jego oczach znamiona prawdziwej apokalipsy) był pozytywny model w postaci bohatera wyzwolonego (lub wyzwalającego się) z pułapek racjonalistycznego światopoglądu i otwartego na transcendencję. Doskonały wzorzec takiego człowieka to właśnie dziecko, któremu wśród ludzi dorosłych odpowiadają szaleńcy Chrystusowi. Łączą ich takie cechy, jak bezwzględna wiara, prostota myślenia w oderwaniu od społecznych schematów, gotowość do poświęcenia. Znamienne są tutaj słowa, które wypowiada Stalker, nawiązujące jednocześnie do Biblii, filozofii Laozi i Gry szklanych paciorków Hermanna Hessego ${ }^{64}$ :

${ }^{60}$ P. Green, dz. cyt., s. 11.

${ }^{61}$ Na przykład w Zwierciadle większość scen to ciąg wizji, wspomnień, snów Aleksieja. Z kolei w niektórych interpretacjach Ofiarowania znaczaca część filmu miałaby rozgrywać się we śnie Aleksandra. Por. S. Kuśmierczyk, dz. cyt., s. 409-410 (porównanie struktury Ofiarowania do wstęgi Möbiusa) oraz 415-419 (przegląd różnych interpretacji Ofiarowania).

${ }^{62}$ Potencjalnie najtrudniejszą do obronienia w takiej interpretacji scena jest zakończenie Stalkera, o którym Green pisze, że szklanki mogą być przesuwane przez przejeżdżający pociąg (s. 139, przyp. 31). Jednak pociag wyraźnie nadjeżdża już po przesunięciu szklanek po blacie. Być może Tarkowski w niekonwencjonalny sposób pokazuje tutaj Martyszkę wyobrażająca sobie, że przesuwa naczynia siłą woli, podczas gdy w rzeczywistości ruch powodują wywołane przez przejazd pociagu wibracje. To niewątpliwie scena otwarta na różne interpretacje.

${ }^{63}$ P. Green, dz. cyt., s. 11.

${ }^{64}$ Por. S. Kuśmierczyk, dz. cyt., s. 338 (przyp. 153). 
Niech się spełni to, co jest sądzone. Niech oni uwierzą. I niech się pośmieją ze swoich namiętności. Bo to, co oni nazywają namiętnościa, w rzeczywistości nie jest energia duchowa, lecz jedynie konfliktem pomiędzy duszą a światem zewnętrznym. A przede wszystkim niech uwierzą w siebie. I staną się bezradni jak dzieci, ponieważ słabość jest wielka, a siła jest niczym. W chwili narodzin człowiek jest słaby i wiotki, w chwili śmierci - twardy i sztywny. Gdy drzewo rośnie, jest delikatne i łamliwe, kiedy usycha i marnieje, umiera. Twardość i siła to towarzysze śmierci. Giętkość i słabość są przejawami życia. To, co zatwardziałe, nigdy nie wygra ${ }^{65}$.

Za przejaw owej twardości można uznać na przykład niezdolność Eugenii do uklęknięcia w jednej z pierwszych scen Nostalgii. Gest ukorzenia się, poniżenia, podporządkowania uwłaczałby jej godności - jednak Tarkowski pokazuje, że w słabości nie kryje się upokorzenie, ale duchowa siła, która pozwala otworzyć się na transcendencję dająca nadzieję na wieczny żywot człowieka. Tę gotowość do wyrzeczenia się doczesności w imię wyższych celów można uznać za główną cechę konstytutywną dla zbliżających się do ideału bohaterów Tarkowskiego.

Rozwój związanej z ideałem dziecka postawy najlepiej prześledzić chronologicznie, dzięki czemu widoczne stana się stopniowe zmiany w jej stosowaniu przez Tarkowskiego. W Walcu i skrzypcach dostrzec można co najwyżej jej zalążki. Siergiej chętniej nawiązuje relację z małym Saszą niż z flirtująca z nim robotnica ${ }^{66}$, a jego wrażliwość pozwala mu dostrzec piękno w muzyce chłopca. Także w kolejnych filmach dorośli, których otaczają dzieci, będa przeważnie reprezentowali pozytywne (w oczach Tarkowskiego) wartości. Podobnie jak w filmie dyplomowym, w Dzieciństwie Iwana nie ma bohaterów jednoznacznie naśladujących dzieci. Oficerowie to dobrzy ludzie, którzy dbaja o Iwana i czuja się za niego odpowiedzialni, ale ich ubolewanie nad poniesiona przez chłopca krzywdą w postaci utracenia przezeń szczęśliwego dzieciństwa nie łączy się u nich z analogiczną obserwacją dotycząca samych siebie. Z kolei Masza sama jest jeszcze blisko wieku dziecięcego i znajduje się w podobnej sytuacji, co Iwan. Jest jednak w Dzieciństwie Iwana jeszcze inny bohater, którego Sean Martin wskazuje jako jednego ze świętych głupców - to staruszek na pogorzelisku ${ }^{67}$. Sam Tarkowski w Czasie utrwalonym nazywa go „obłąkanym”68, ale postać ta nie ma wyraźnego rysu szaleńca Chrystusowego. Owszem, mówiąc o swej zabitej przez Niemców matce, staruszek enigmatycznie stwierdza, że ona wróci, a on wyszykuje izbę na jej przyjście. Czyni to jednak, wieszając na kominie (który jako jedyny zachował

${ }^{65}$ Cyt. za: R. Rutkowski, dz. cyt.

${ }^{66}$ Por. tamże.

${ }^{67}$ S. Martin, dz. cyt., s. 36.

${ }^{68}$ A. Tarkowski, Czas utrwalony..., s. 33. Tarkowski opisuje tam wymyśloną na etapie pisania scenariusza alternatywną wersję sceny ze staruszkiem, którą po czasie uznał za lepsza. 
się z jego domu) oprawiony w ramkę certyfikat honorowy ${ }^{69} \mathrm{z}$ wizerunkami Lenina i Stalina - nagrody otrzymane od totalitarnych władz i sympatie komunistyczne kłóca się w świecie Tarkowskiego z postawą wewnętrznej wolności i pielęgnowania własnej duchowości, a z pewnością nie sygnalizują szaleńca Chrystusowego. Ponadto, to bohater raczej gadatliwy, a - jak wskazuje Birzache - jednym z podstawowych rysów pasywnego świętego głupca (a do tej kategorii należałoby go zaliczyć) jest milczenie ${ }^{70}$. Nagromadzenie tych różnych, niezbyt spójnych sygnałów świadczy raczej o kreacji staruszka na zasłużonego socjalistycznej ojczyźnie człowieka, który w obliczu wojennych zniszczeń okazuje się bezbronny, samotny i przestraszony i w którym tęsknota za matką budzi irracjonalną wiarę w możliwość jej powrotu, niż na postać wzorowaną na szaleńcu Chrystusowym.

Pierwszą pełnoprawną i bez wątpienia świadomie nawiązująca do jurodstwa postacia jest więc „dziewka niespełna rozumu” (jak śpiewał o niej Jacek Kaczmarski) z Andrieja Rublowa ${ }^{71}$. Wpisuje się ona w typ błogosławionego idioty: jest niema, kieruje się emocjami, nie myśli racjonalnie - zachowuje się niczym dziecko. Plamy rozchlapanej przez Rublowa w gniewie farby, które pokrywaja biała ścianę świątyni, wywołuja w niej histeryczna reakcję. Utwierdza to ikonopisa w przekonaniu, że nie może malować Sądu Ostatecznego zgodnie z obowiązującym kanonem, gdyż przestraszy ludzi zamiast pomagać im w pielęgnowaniu w sobie dobra. Błażenna jest więc pars pro toto ludu ruskiego; Birzache pisze nawet, że uosabia ona „Święta Ruś" i ideał wspólnoty przeciwstawny wszelkim tendencjom autokratycznym. Dziecięca postawa duroczki splata się tutaj z jej funkcją krytyczną jako świętego głupca - choć nie głosi ona aktywnie postulatów odnowy społeczeństwa, samo jej istnienie jako osoby wyzwolonej (ze względu na chorobę psychiczna) spod władzy społecznych mechanizmów kwestionuje panujący na Rusi porządek ustanowiony przez żądnych władzy możnych. Prostota umożliwia jej nawet, jako jedynej postaci w filmie (wyłączywszy Małego Księcia, którym powodują czysto egoistyczne pobudki), nawiązanie więzi z Tatarami: „Przez krótką chwilę naśmiewający się z jej prostoty Tatar przypatruje się jej oczom z wyraźna fascynacja: to moment porozumienia niewymagającego słów, zaglądania w głąb drugiej osoby i dostrzegania tam czegoś - w jej totalnej delikatności i miłosierdziu tkwi obraz Innego. Może jest więc szansa na odkupienie nawet tych, którzy ucieleśniają zło?"72.

\footnotetext{
${ }^{69}$ Rosyjski napis na nim głosi: „Почетная грамота”.

${ }^{70}$ A.G. Birzache, dz. cyt., s. 83.

${ }^{71}$ Por. J. Kaczmarski, Rublow, <https://www.kaczmarski.art.pl/tworczosc/wiersze/rublow/> [dostęp: 15.09.2019]. Kuśmierczyk nazywa bohaterkę „Błażenną”, Birzache (za scenariuszem filmu) używa określenia „duroczka” (ang. durochka, ros. дурочка).

${ }^{72}$ A.G. Birzache, dz. cyt., s. 86-87.
} 
Podobieństwa do szaleńca Chrystusowego, choć tym razem z drugiego końca spektrum, przejawia także skomoroch, czyli pojawiający się na początku filmu błazen. Jego zachowanie zbliża go do typu psotnika, który krytykuje społeczeństwo przez jego wyszydzenie ${ }^{73}$. Wydaje się jednak, że ta analogia jest dość powierzchowna: intencja skomorocha nie jest bowiem krytyka, a dostarczenie widzom zabawy. Bardziej uzasadnione jest z kolei wskazanie jako postaci pokrewnej jurodiwemu Teofana Greka. Nie jest on oczywiście szaleńcem Chrystusowym sensu stricto - nie wyrzeka się przecież swej nobilitującej go profesji, nie podważa swym zachowaniem panujących zasad. To bardziej potencjalny jurodiwy, który być może zdecyduje się na jurodstwo dobrowolne ${ }^{74}$. W czasie rozmowy z Rublowem po jego stopach chodzą mrówki, co pozwala kojarzyć go z upokarzającym się cieleśnie asceta. Z kolei we wcześniejszej scenie z Kiriłem Teofan wyznaje, że użył ikony do wyciskania kapusty - w jego postaci mądrość łączy się ze śmiesznością. Leżącą pozycję, w której mnich rozpoczyna tę rozmowę Birzache odczytuje jako wizualną metaforę ilustrująca ideę, że w królestwie Bożym wartości ziemskie zostają odwrócone ${ }^{75}$. Tak jak mówił Stalker: słabość zwycięża nad siła, giętkość nad twardościa, wiara nad rozumem, dziecko nad dorosłym.

W obliczu powyższych ustaleń paradoksalny może się wydać sposób, w jaki Kuśmierczyk interpretuje obecność motywu dziecka w Andrieju Rublowie. Badacz wykazuje, że pojawia się on w porządku triadycznym (który jest ogólną zasadą dotyczącą również wielu innych postaci i motywów w filmie $^{76}$ ). Trzykrotnie pojawiające się dzieci to: w noweli Skomoroch. $1400 \mathrm{r}$. dziewczynka w chacie, z którą Rublow spotyka się spojrzeniami i szybko odwraca wzrok, w noweli Pasja wedtug Andrieja. 1406 r. dziecko obserwujace ukrzyżowanie Chrystusa w wizji Rublowa oraz w noweli Sqd Ostateczny. 1408 r. mała księżniczka w retrospekcji Rublowa. Dodatkowo w ostatniej z wymienionych scen bohater recytuje Hymn o miłości z Pierwszego Listu do Koryntian, pomijając kilka ostatnich wersów. Kuśmierczyk interpretuje obecność motywu dziecka następująco:

W Andrieju Rublowie dziecko jest związane z postacia głównego bohatera. Może uobecniać niedojrzałość jego spojrzenia na świat. Pominięty przez Rublowa fragment Hymnu o mitości jest argumentem potwierdzającym zasadność takiej hipotezy. „Gdy

${ }^{73}$ Tamże, s. 84.

${ }^{74} \mathrm{~W}$ czasach staroruskich „chwilowe jurodstwo”, a więc przebywanie w stanie jurodstwa jedynie przez pewien czas, było normalną praktyką. Por. S. Kuśmierczyk, dz. cyt., s. 296.

${ }^{75}$ A.G. Birzache, dz. cyt., s. 84.

${ }^{76}$ Analogicznie Kuśmierczyk opisuje obecność postaci Błażennej: najpierw w scenie z plamami farby na ścianie, później w czasie najazdu na Włodzimierz i wreszcie w scenie bicia w dzwon. Badacz pomija jednak epizod, w którym bohaterka odjeżdża z Tatarami, być może uznając go za kontynuację części dotyczącej najazdu. Por. S. Kuśmierczyk, dz. cyt., s. 135. 
zaś przyjdzie to, co jest doskonałe, zniknie to, co jest tylko częściowe. Gdy byłem dzieckiem, mówiłem jak dziecko, czułem jak dziecko, myślałem jak dziecko. Kiedy zaś stałem się mężem, wyzbyłem się tego, co dziecięce”. W zakończeniu pierwszej części filmu zawarta zostaje informacja, że bohatera czekają dalsze próby ${ }^{77}$.

Wartościowanie dzieciństwa i dojrzałości jest tu odwrotne względem tego, które zawarte jest w całokształcie twórczości Tarkowskiego. Jednak motyw dziecka, trafnie wskazany przez Kuśmierczyka, daje się też odczytać w inny sposób, który nie stoi w sprzeczności z zasadniczą funkcją dziecka, jakąjest uosabianie ideału. Rublow odwraca wzrok, uginając się pod czystym, wyrażającym duchową siłę spojrzeniem dziewczynki. Z kolei dziecko obserwujące ukrzyżowanie uśmiecha się do Chrystusa. Jego reakcja kontrastuje z lamentem pozostałych zgromadzonych, ale pozostaje w zgodności z wypowiadanymi przez Rublowa słowami opisującymi scenę: skoro Chrystus przyszedł od Boga, musiał być wszechmogacy, a jego męka - dobrowolna. Ukrzyżowanie to pojednanie Boga z człowiekiem. Spośród wszystkich zgromadzonych tylko dziecko pojmuje sens tego zdarzenia na tyle głęboko, aby móc cieszyć się z cierpienia Jezusa. Zabawa z księżniczką to z kolei moment, w którym Rublow wkracza na chwilę w świat dziecięcej beztroski. Dziewczynka ochlapuje go mlekiem, które symbolicznie wiąże się z dzieciństwem, jak gdyby naznaczając go do podążania w kierunku ideału. Argument dotyczacy nieprzytoczonego przez Rublowa fragmentu Hymnu o miłości jest nieprzekonujący: Rublow urywa recytację w sposób naturalny, w wyniku reakcji na zachowanie księżniczki, nie omija więc tych konkretnych słów celowo. Cytowany przez Kuśmierczyka fragment Hymnu ostatecznie nie pojawia się w filmie: jego pominięcie przez Tarkowskiego może wynikać właśnie z tego, że jego wymowa kłóciłaby się z wydźwiękiem sceny i znaczeniem motywu dziecka w całym dziele ${ }^{78}$. Rublow dąży do ideału jako artysta i dopiero w ostatniej scenie noweli Dzwon. 1423 r. go osiaga. Pod wpływem obserwowania Boryski znajduje w sobie na powrót utraconą wiarę w dany mu przez Boga talent oraz w posłannictwo, które się z nim wiąże. Od tej chwili jest gotów tworzyć arcydzieła, co zostaje podkreślone poprzez umieszczenie po omawianej scenie barwnego epilogu prezentujaccego jego

${ }^{77}$ S. Kuśmierczyk, dz. cyt., s. 161-162.

${ }^{78}$ Końcówka Hymnu o miłości pojawia się w pierwotnej wersji filmu z 1966 roku noszącej tytuł Pasja wedtug Andrieja (ros. Cтрасти по Андрею). Tam jednak umieszczona jest przed początkowymi partiami tekstu. Wraz z ostatnim wersem Hymnu rozpoczyna się introspekcja Rublowa, który kontynuuje recytację od początku utworu. Tarkowski wyciął końcowe wersy Hymnu ze ścieżki dźwiękowej podczas dokonywania zmian w filmie. Kuśmierczyk wyraża przypuszczenie, że powodem takiego działania było banalne użycie słów z końcówki Hymnu do skontrastowania zachowania Fomy z postawą Rublowa w scenie poprzedzającej introspekcję. Usunięcie fragmentu podniosło więc jakość artystyczną całej sceny. Por. S. Kuśmierczyk, dz. cyt., s. 121-122. 
ikony. Choć Rublow daleki jest od postaci szaleńca Chrystusowego, jurodiwi i artyści poniekąd dzielą funkcję krytyczną wobec społeczeństwa, cechując się wewnętrzną wolnością ${ }^{79}$. Ponadto, Birzache dostrzega w przyjęciu przez Rublowa podczas najazdu na Włodzimierz ślubu milczenia (co bohater czyni na znak pokuty po zabiciu człowieka w obronie duroczki) charakterystyczny dla pasywnego świętego głupca „akt sprzeciwu wobec powszechnej moralności i zwyczajów" ${ }^{\prime 0}$. Nie wyjaśnia niestety, na czym dokładnie miałby ów sprzeciw polegać.

W dwóch kolejnych filmach Tarkowskiego, Solaris i Zwierciadle, brak postaci odwołujących się do typu szaleńca Chrystusowego. Nie znaczy to jednak, że bohaterowie tych filmów nie pozostaja w relacji do uosabianego przez dziecko ideału. Oba dzieła opowiadają o wyrzutach sumienia człowieka, który skrzywdził swoich bliskich. W Solaris inteligentny ocean materializuje na stacji kosmicznej Harey, zmarłą żonę głównego bohatera, Krisa. Ten obwinia się o jej śmierć, wierząc, że spowodował ją własnym zaniedbaniem. Jednak jego reakcja na pojawienie się „gościa” (tak kosmonauci nazywają owe materializacje) różni się znacząco od postaw dwóch pozostałych mieszkańców stacji, Snauta i przede wszystkim Sartoriusa. Ten drugi traktuje "gości" jako zjawiska naukowe, jest oschły, zimny, stanowczo odradza angażowanie się emocjonalnie w zaistniała sytuację. Jednak Kris coraz bardziej dostrzega w Harey człowieka i zaczyna darzyć ją uczuciem. Zachowuje się irracjonalnie, wykazując w obliczu niecodziennych zdarzeń gotowość do ich przyjęcia i zaakceptowania. Widać tu wielokrotnie stosowana przez Tarkowskiego zasadę kontrastu, która uwydatnia postawy bohaterów, często zgrupowanych w trójki, z dwoma z nich reprezentującymi skrajności i jednym umieszczonym pośrodku. Takie konstelacje w kolejnych filmach to: Rublow-Danił-Kirił w Andrieju Rublowie, Stalker-Pisarz-Profesor w Stalkerze, Domenico-Gorczakow-Eugenia w Nostalgii, Maria-Alexander-Adelajda (i Victor) z Ofiarowania, czy właśnie Kris-Snaut-Sartorius w Solaris.

Wyróżnienie podobnej trójki w przypadku Zwierciadła jest znacznie trudniejsze ze względu na złożoność filmu, choć układ Maria-Aleksiej-Natalia zdaje się wpisywać w możliwą do zaobserwowania na przykładzie triad z innych filmów tendencję: pierwsza z postaci zbliża się najbardziej do ideału, natomiast trzecia jest od niego najdalsza. Kontrast między matką i żoną (Marią i Natalia) jest tym wyraźniejszy, że obie postaci gra ta sama aktorka, Margarita Tieriechowa. Korzystając ze swej unikalnej perspektywy przed-

${ }^{79}$ Tarkowski wyraźnie odróżniał wewnętrzną wolność człowieka od jego praw, twierdząc, że nawet w najbardziej opresyjnych warunkach możliwe jest bycie wolnym „w najgłębszym sensie tego słowa”. Por. Zwierciadło. Andriej Tarkowski w rozmowie z Jerzym Illgiem i Leonardem Neugerem, oprac. J. Illg, L. Neuger, Kraków 2016, s. 84.

${ }^{80}$ A.G. Birzache, dz. cyt., s. 84 i 86. 
stawicielki tego samego co Tarkowski pokolenia Rosjan, Maja Turowska wyjaśnia różnicę między bohaterkami: „Tarkowski dał swej głównej aktorce nie lada zadanie: zagrać podobną bohaterkę w dwóch okresach czasu - jako przedwojenną kobietę i jej "wyemancypowaną" powojenną odpowiedniczkę. Margarita Tieriechowa wywiązała się z tego zadania znakomicie. Odtwarza zarówno starodawna, delikatna, choć twardą kobiecość naszych matek, jak i brawurę dzisiejszych kobiet, których samowystarczalność i wolność to druga strona samotności" ${ }^{2}$. Poglądy Tarkowskiego na temat roli kobiet pozwalaja sądzić, że nisko wartościował on ów „wyemancypowany” typ. Jego zdaniem kobieta powinna przede wszystkim zachować kobiecość, a w związku podporządkować swój wewnętrzny świat światu wewnętrznemu mężczyzny. Za istotę kobiecej miłości uznawał zdolność do samorezygnacji i totalnego oddania się mężczyźnie; krytykował kobiety zmieniające życiowych partnerów i żyjące niezależnie od mężczyzn ${ }^{82}$. Łatwo zdeprecjonować te wypowiedzi jako mizoginiczne, seksistowskie i protekcjonalne wobec kobiet: Tarkowski zdaje się w swoim mniemaniu wiedzieć lepiej od nich, co jest dla nich dobre, a co nie. Jednak warto też zauważyć, że - w kontekście całego jego światopoglądu - kieruje nim troska o dobro przedstawicielek płci przeciwnej, pojęte jako możliwość duchowego rozwoju. Ze względu na swoją niższą od mężczyzny pozycję społeczną i ogólne oczekiwanie podporządkowania się ojcu, bratu bądź mężowi, kobiety są potencjalnie bliższe ideałowi dziecka; od gotowości do totalnego oddania się mężczyźnie nie jest bowiem daleko do bezwzględnej wiary w Boga. Związek Aleksieja z Natalią rozpadł się zapewne właśnie dlatego, że nie byli oni w stanie osiagnąć duchowego zjednoczenia. Czy stało się to $\mathrm{z}$ winy Natalii? Niewatpliwie zależy to od punktu widzenia: z perspektywy Aleksieja, będącego alter ego Tarkowskiego, zapewne tak.

Przy wartościowaniu postaci Zwierciadła subiektywizm narracji tegoż filmu odgrywa kluczową rolę. Matkę można uznać za przeciwstawiony żonie ideał jedynie przy założeniu, że oglądana jest ona oczami syna. Obie kobiety wiele przecież łączy: rozpad związku, samotne życie i wychowanie dzieci na własną rękę. Jednak wydarzenia z życia Marii są zarazem wspomnieniami Aleksieja z dzieciństwa, wypełnionymi nastrojem szczęścia i cudowności. Istnieje zasadnicza różnica między ukazaniem rozpadu związku jako ciagu nieprzyjemnych rozmów a opowiedzeniem o nim w postaci poetyckiej wizji rozsypującego się domu. Postać Marii jest w Zwierciadle, oczywiście tylko do pewnego stopnia, wyidealizowana. Wiąże się to z ogromnym znaczeniem, jakie dla Tarkowskiego miała jego własna matka. Zwierciadło jest

${ }^{81}$ M. Turovskaya, dz. cyt., s. 66.

${ }^{82}$ Zbiór wypowiedzi z różnych źródeł zebranych w: A. Tarkowski, Kompleks Totstoja..., s. $41-44$. 
filmem otwarcie autobiograficznym, osnutym na kanwie wspomnień reżysera z dzieciństwa. Ponad dekadę po realizacji filmu wyznał on: „po prostu cały świat jest dla mnie związany z matką. Przy czym ja nie bardzo dobrze zdawałem sobie z tego sprawę, dopóki ona żyła" ${ }^{\prime 3}$. Nawet jeśli matka nie uosabia w Zwierciadle ideału, dla wspominającego ją syna taką się właśnie wydaje. Poświęcenie, z którym samotnie wychowuje dzieci zapowiada zaś ogromnie ważny w późniejszych dziełach Tarkowskiego motyw ofiary. Reżyser wskazywał też w wywiadzie, że dzięki złożonej strukturze czasowej filmu postać Marii zostaje ukazana w relacji z transcendencja: „Ważne było dla mnie pokazanie, że ta postać czy też dusza matki jest nieśmiertelna" ${ }^{84}$. Dlatego też kilkakrotnie wiek Marii zmienia się w ramach jednej sceny: najpierw gra ja Tieriechowa, a po chwili prawdziwa matka Tarkowskiego, Maria Iwanowna. Z kolei w zakończeniu filmu obie postaci pojawiają się na ekranie jednocześnie (choć młoda matka stoi daleko na środku pola). Wyrażona tu nadzieja na nieśmiertelność duszy i trwanie życia po śmierci jest fundamentalna dla światopoglądu Tarkowskiego i uzasadnia prezentowany przezeń ideał wiary i ufności.

Aleksiej, narrator Zwierciadta, znajduje się między tymi dwiema kobietami: matka, która przypomina mu o szczęściu dzieciństwa, i Natalia, reprezentująca pełną rozczarowań teraźniejszość. Podobnie jak Kris w Solaris bohater cierpi z powodu wyrzutów sumienia. Wie, że jest egoistą i że krzywdził ludzi, którzy go kochali, wie, że nie kochał ich dość mocno, że nie był zdolny do odwzajemnienia ich uczucia. Kluczowa dla zrozumienia Zwierciadta jest scena śmierci narratora, na którą Tarkowski wskazywał jako na jedyna nieoparta na prawdziwych wydarzeniach z historii jego rodziny. „[T]en bardzo interesujący epizod był konieczny, ażeby opowiedzieć o kryzysie duchowym autora, o stanie jego ducha. Być może jest on śmiertelnie chory i być może właśnie to wywołuje wspomnienia, które układaja się w ten właśnie film - jak u człowieka, który przed śmiercią przypomina sobie najważniejsze chwile swego życia. [...] [T]o wspomnienia człowieka umierającego, rozważającego wspomniane epizody w swoim sumieniu" ${ }^{5}$. W dialogu, który w omawianej scenie dwie kobiety (grane przez te same aktorki co tajemnicza kobieta od listu Puszkina i jej pokojówka) prowadzą z lekarzem, zostaje wspomniane poczucie winy bohatera. Dostrzegł on własne błędy i za nie żałuje, powoli stając się zdolnym do prawdziwej miłości, pełnej poświęcenia i oddania. Jednak

${ }^{83}$ Zwierciadto..., s. 59-60. Maria Iwanowna Tarkowska umarła w 1979 roku, pięć lat po realizacji Zwierciadta.

${ }^{84}$ Tamże, s. 79.

${ }^{85}$ Tamże, s. 46-47. 
śmierć przerywa jego duchowe zmagania z samym soba, zatrzymując go w pół drogi ku ideałowi ${ }^{86}$.

Jest jeszcze jedno - poza wyrzutami sumienia bohaterów - podobieństwo między Solaris i Zwierciadtem: w obu filmach następuje tęskne spojrzenie na własne dzieciństwo. W Zwierciadle podróż przez pamięć narratora tworzy zasadniczą część struktury filmu. Z kolei w Solaris nośnikiem wspomnień staje się stare nagranie, które Kris pokazuje Harey. Przedstawia ono sceny z dzieciństwa bohatera, pojawiają się postaci jego ojca i nieżyjącej już matki. Ta druga powraca też w scenie majaków Krisa pod koniec filmu - jest w niej niezwykle podobna do Harey, od tyłu wręcz nie do odróżnienia; obie noszą to samo ubranie i na zmianę wchodzą i wychodzą z kadru. W dalszej części wizji następuje rozmowa Krisa z matką w scenerii będącej dziwaczną fuzją rodzinnego domu bohatera ze stacją kosmiczną. Wyraźnie wyczuwalna jest jego tęsknota za zmarłą i za jej troskliwą opieką w czasie dzieciństwa. Zarówno w Solaris, jak i w Zwierciadle targani wyrzutami sumienia bohaterowie wspominają własne dzieciństwo, w czym wyrażona zostaje również ich tęsknota za ideałem. Motyw ten znajdzie swoją kontynuację w trzech ostatnich filmach Tarkowskiego.

Jeśli Solaris i Zwierciadto łączą się w dylogię o sumieniu, Stalker, Nostalgia i Ofiarowanie to tryptyk o apokalipsie. W każdym kolejnym z tych filmów jej nadejście wydaje się coraz bardziej nieuchronne. Krajobrazy Stalkera przywodzą na myśl pozostałości po katastrofie nuklearnej bądź ekologicznej. W Nostalgii Domenico stara się unaocznić ludziom wszechogarniającą duchowa pustkę. Wreszcie w Ofiarowaniu apokalipsa niemal się wydarza: zapobiega jej jedynie ofiara Alexandra (w jednej z możliwych interpretacji filmu). Koniec świata odbywa się nie tylko w sferze materialnej, ale przede wszystkim duchowej. Tęsknota Krisa i Aleksieja za własnym dzieciństwem zmienia się tu w tęsknotę za dzieciństwem ludzkości, za czasami, w których ludzie byli zdolni do wiary. W Stalkerze pierwsze wypowiadane przez Pisarza słowa to:

${ }^{86}$ Por. R. Rutkowski, dz. cyt. Przy okazji omawiania Zwierciadła warto zwrócić uwagę na podobieństwo duchowej prostoty (postulowanej przez Tarkowskiego w postaci uosabianego przez dziecko ideału) z opisywana przez niego postawą widzów najtrafniej rozumiejących jego film. To nie wykształcenie, a poziom rozwoju duchowego decyduje o odbiorze jego kina. Reżyser pisze o tym m.in. we wstępie do Czasu utrwalonego, taki jest też sens przytaczanej przez niego anegdoty o sprzątaczce (por. A. Tarkowski, Kompleks Totstoja..., s. 182). Najprecyzyjniej wyraził tę myśl w jednym z wywiadów: „Ludzie prości, mniej przygotowani, którzy nie starają się zrozumieć, rozumieja, w porównaniu z tymi, którzy uważają się za znawców, więcej i szybciej. [...] Zwierciadto jest w rzeczywistości przewidziane tylko dla osób inteligentnych, ale nie w sensie wykształcenia, lecz otwartości umysłu i duszy" (źródło: Conservare le radici, rozm. L. Capo, „Scena” 1980, nr 1, s. 50, przeł. M. Jurewicz, za: A. Tarkowski, Kompleks Totstoja..., s. 183). 
[...] nasz świat jest beznadziejnie nudny. A zatem takie rzeczy jak telepatia czy przywidzenia, czy latające spodki po prostu nie mogą istnieć. Światem rządzą żelazne prawa, które czynia go nieznośnie nudnym. [...] Życie w średniowieczu było ciekawsze. Każdy dom miał swojego skrzata, a każdy kościół miał Boga.

W podobnym duchu wypowiada się w Nostalgii Domenico w scenie na rzymskim Campidoglio:

Prawdziwym złem naszych czasów jest to, że nie ma już wielkich mistrzów. [...] Musimy napełnić nasze oczy i uszy rzeczami, które sa początkiem wielkiego marzenia. Ktoś musi zakrzyknąć, że zbudujemy piramidy. Nieważne, jeśli ich nie zbudujemy. Musimy podsycać to pragnienie i rozciagnać duszę niczym niekończące się prześcieradło. Jeśli chcecie, aby świat szedł naprzód, musimy trzymać się za ręce.

Te wypowiedzi dopełnia skierowany do Malca monolog Alexandra, który w jednej z pierwszych scen Ofiarowania diagnozuje fatalny stan nowoczesnej cywilizacji technicznej:

Człowiek zawsze tylko się bronił - przed innymi ludźmi, przed natura, której jest częścią. Ciagle gwałcił naturę. I w rezultacie powstała cywilizacja, która opiera się na sile, władzy, strachu i zależności. I cały nasz tak zwany postęp techniczny ciagle służył tylko pozyskaniu wszelkiego rodzaju wygodnictwa, standardu czy tė̇ instrumentu przemocy w celu zachowania władzy. Jesteśmy jak dzicy - używamy mikroskopu jak kija. Zresztą nie - dzicy są o wiele bardziej uduchowieni niż my. Każdy naukowy postęp natychmiast przekształcamy w coś złego. A co się tyczy standardu, to pewien mądry człowiek powiedział, że grzech - to jest to, co nie jest niezbędne. I jeśli jest tak, jak jest, to dlatego, że cała nasza cywilizacja od początku do końca opiera się na grzechu. Mamy straszną dysharmonię, to znaczy brak równowagi pomiędzy rozwojem materialnym a duchowym. Jest jakiś błąd w naszej kulturze, dokładniej mówiąc w naszej cywilizacji, podstawowy błąd, synku. Myślisz pewno, że należy zbadać ten problem, a potem wspólnie poszukać jakiegoś wyjścia. Być może dałoby się to zrobić, gdyby nie było tak późno. Całkowicie za późno.

Jedynym ratunkiem w tej rozpaczliwej sytuacji jest zwrócenie się w stronę ideału. Warto przyjrzeć się dokładniej wspomnianym konstelacjom bohaterów, aby prześledzić zmiany w wizji Tarkowskiego zachodzace z filmu na film. Do wyróżnionych już wcześniej triad można w przypadku Stalkera i Nostalgii dołożyć czwarta, najbliższą ideału postać: odpowiednio Żonę Stalkera oraz Marię, żonę Gorczakowa. Obie pojawiają się na krótko i uosabiaja bezwzględną miłość. Zasadnicza różnica między nimi polega jednak na tym, że Żona Stalkera mówi o swym poświęceniu dla męża w monologu skierowanym wprost do widza, podczas gdy Maria pojawia się jedynie w wizjach Gorczakowa. W Nostalgii bowiem, podobnie jak w Zwierciadle, subiektywizm odgrywa istotna rolę. Maria uosabia dla Gorczakowa ojczyznę, za która ten tęskni, a także ideał, ku któremu chciałby dążyć. Jej przeciwieństwem 
jest Eugenia. Czysta, „święta” miłość Marii (Maja Turowska opisuje, jak żona kojarzy się Gorczakowowi z obrazem Madonny Piera della Francesca ${ }^{87}$ ) kontrastuje z próba uwiedzenia bohatera przez Eugenię. Z kolei w Ofiarowaniu postać najbliższa ideału jest już znacząco inna: tym razem to nie żona bohatera, a służąca w jego domu, Maria. Rafał Rutkowski słusznie wymienia jako „duchowe dziecko” również drugą służąca, Julię, ze względu na jej troskę o Malca ${ }^{88}$, ale Maria jest jednak dalece istotniejszą dla rozwoju zdarzeń bohaterka. To z jednej strony osoba głęboko wierząca, z drugiej jeśli wierzyć słowom Otta - czarownica. Dzięki enigmatycznej, onirycznej narracji w Ofiarowaniu nie do końca wiadomo, co zaszło i jak należy interpretować postać służącej, jej rolę w fabule czy jej związki z tajemnymi siłami. Czy katastrofy udało się uniknąć dzięki modlitwie Alexandra, czy dzięki mocom Marii, czy może w ogóle nie było żadnego zagrożenia? Dla każdej z tych wersji zdarzeń można by znaleźć w filmie zarówno potwierdzenia, jak i zaprzeczenia, a różne interpretacje stawiałyby też w różnym świetle związki Marii z transcendencja.

Stopniowy zwrot Tarkowskiego ku coraz mniej jednoznacznym rozwiązaniom formalnym nie jest jedynym wyraźnym trendem, który można zaobserwować w jego późnej twórczości. Z jednej strony, bliskie ideału bohaterki sa coraz odleglejsze od głównego bohatera: w Stalkerze to wytrwale trwająca u boku męża Żona, która w imię miłości znosi wszelkie trudy i znajduje szczęście w nawet najbardziej nieszczęśliwym położeniu; Maria z Nostalgii została w Rosji, bohater nie ma z nią kontaktu, może jedynie oglądać ją w swych wizjach; wreszcie Maria z Ofiarowania, związana z Alexandrem jedynie zawodową relacja, tajemnicza, pochodząca z obcego kraju, małomówna, mistyczna. W miarę, jak wizja Tarkowskiego coraz bardziej się radykalizuje, ideał oddala się od bohatera. Analogiczny ruch następuje również po drugiej stronie spektrum filmowych postaci, a więc wśród odległych od ideału racjonalistów, materialistów. Są to Profesor w Stalkerze, Eugenia w Nostalgii oraz Adelajda i Victor w Ofiarowaniu. W każdym kolejnym filmie nadzieja na ich otrząśnięcie się z otępiającego stanu, w którym zostają ukazani wydaje się coraz mniejsza. Profesor rezygnuje ze swego planu wysadzenia Strefy i rozbiera bombę, dostrzegając ostatecznie wartość tkwiąca w nadziei. Eugenia w pożegnalnej rozmowie telefonicznej z Gorczakowem okazuje troskę, pytając go o jego samopoczucie i stan zdrowia; nie wydaje się jednak rozumieć, skąd biora się rozterki Rosjanina, podobnie jak nie pojmuje zachowania Domenica, którego przemowy porównuje z wiecami Fidela Castro. W Ofiarowaniu jedyna, raczej hipotetyczna, nadzieją na zwrócenie

\footnotetext{
${ }^{87}$ M. Turovskaya, dz. cyt., s. 124.
}

${ }^{88}$ R. Rutkowski, dz. cyt. 
się Adelajdy i Victora w stronę ideału jest wstrząs wywołany spłonięciem domu, jednak Tarkowski nie precyzuje dalszych losów tych bohaterów.

Obserwowane tutaj zmiany w kreacji bohaterów, wyznaczające kierunek rozwoju refleksji reżysera nad współczesnością, dotyczą oczywiście w równej, jeśli nie większej mierze także tych postaci, które znajdują się pośrodku owego wyznaczonego odległością od ideału spektrum. Sa to dwie grupy bohaterów: jurodiwi i bohaterowie „w drodze”. Do jurodiwych należą Stalker i Domenico, bohaterami „w drodze” są zaś Pisarz i Gorczakow. Alexander to przypadek szczególny, który z bohatera „w drodze” staje się jurodiwym.

W scenie na progu Komnaty Pisarz określa Stalkera mianem „jurodiwego”, natomiast Żona w swym monologu mówi o nim: „błażenny” ${ }^{9}$. Faktycznie, bohater wykazuje wiele podobieństw do typu świętego szaleńca. Jest ukazany jako słaby człowiek, już po jego wyglądzie i ubiorze widać, ile przeszedł w życiu ${ }^{90}$, a co najważniejsze - wierzy, że ma misję, której się poświęca. Stalker jest przekonany, że wiara może przynieść ludziom nadzieję i ukojenie. Dlatego prowadzi swych klientów przez strefę, starając się rozbudzić w nich tę wiarę. Podobna jest też misja Domenica, który dąży do wytracenia ludzi z otępienia, w którym tkwia, oderwani od duchowości. Jego poświęcenie jest jednak dalej posunięte - dokonuje bowiem samospalenia. Między Stalkerem a Domenikiem zachodzi też inna istotna zmiana: ten pierwszy ma wątpliwości, kwestionuje sens swej misji wobec niewiary klientów. Domenico jest z kolei całkowicie przekonany o słuszności swego działania. Tak będzie również w przypadku Alexandra. Bohaterowie „W drodze” odpowiadaja grupie postaci poszukujących „duchowego dziecięctwa" u Rutkowskiego, który jednak inaczej odczytuje postać Pisarza, przyporządkowując go do ludzi najdalszych od ideału. Z kolei sam Tarkowski mówił o tym bohaterze: „wyruszył do strefy jako cynik, taki pragmatysta, a wrócił stamtąd jako człowiek, który zaczął mówić o ludzkiej godności, który uświadamia sobie, że jest złym człowiekiem. Po raz pierwszy staje w ogóle przed takim pytaniem, czy człowiek jest zły, czy dobry? A jeżeli on już o tym pomyślał - tym samym wstępuje na drogę" ${ }^{11}$. W Stalkerze bohater „w drodze" zostaje więc poruszony przez jurodiwego do myślenia. W Nostalgii ta relacja zachodzi krok dalej: Domenico porusza Gorczakowa do czynu, czyli symbolicznego przeniesienia świeczki przez basen św. Katarzyny. W jednej z wizji Gorczakow widzi sam siebie w lustrze jako Domenica - ta scena zapowiada następujace w Ofiarowaniu połaczenie bohatera „w drodze” z jurodiwym. Alexander sam podejmuje działanie, bez duchowego przewodnika czy wzorca, jakim byli Stalker i Domenico dla Pisarza i Gorczakowa.

\footnotetext{
${ }^{89}$ Por. wnikliwą analizę jurodstwa Stalkera w: S. Kuśmierczyk, dz. cyt., s. 295-306.

${ }^{90}$ A.G. Birzache, dz. cyt., s. 88-89.

${ }^{91}$ Zwierciadto..., s. 81.
} 
W obliczu katastrofy odnajduje w sobie wiarę jako jedyną ostoję, w której jest jeszcze nadzieja. Poświęca się, aby ocalić ludzi, których kocha. Jak pisze Rutkowski, Alexander odradza się duchowo, osiagając „duchowe dziecięctwo” i ewangeliczny ideał wiary, nadziei i miłości.

Osobnym trendem, który można zaobserwować w trzech ostatnich filmach Tarkowskiego jest wzrastające znaczenie więzi bohaterów z dziećmi. Stalker niewątpliwie kocha córkę, ale znacznie ważniejsza jest dla niego jego misja. Martyszką opiekuje się więc Żona. Wątpiący bohater u progu Komnaty rozważa porzucenie swego zajęcia i przeniesienie się na stałe do strefy, w której jego rodzinie nic nie będzie zagrażać. W podobny sposób postapił kiedyś Domenico, który chcąc ocalić swoich najbliższych przez końcem świata, zamkną się z całą rodziną na 7 lat w domu. Dopiero po czasie zrozumiał, że nie może egoistycznie dążyć do uratowania jedynie siebie i osób, które kocha, i zdecydował się na czyn publicznego samospalenia. Gorczakow ze względu na swój pobyt we Włoszech ma ze swoimi dziećmi jeszcze mniejszy kontakt niż Stalker z córką (choć właściwie należałoby go porównać do Pisarza, który nie nawiązuje relacji z żadnym dzieckiem). Jest jednak w Nostalgii scena, w której dochodzi do interakcji między bohaterem a mała dziewczynka. Pijany Gorczakow przebywa w podtopionym i zrujnowanym kościele, który najbardziej w całych Włoszech przypomina mu Rosję. W ruinach nagle pojawia się dziewczynka, do której bohater wygłasza monolog. Zapytana o imię odpowiada: Angela. Dziecko niemal dosłownie ucieleśnia tutaj ideał, a jego rozmowa $\mathrm{z}$ bohaterem wskazuje na zachodząca $\mathrm{w}$ nim przemianę. W Ofiarowaniu więź z dzieckiem jest najsilniejsza. Alexander bardzo kocha Malca i spędza z nim większość czasu, starając się jak najlepiej przygotować go do życia. Ofiara, która składa, łączy w sobie wymiar prywatny i globalny: ratując świat przed zagłada, Alexander ratuje też swą rodzinę. Bliską relację z chłopcem ma też wspomniana już służąca Julia i, jak można przypuszczać, Maria, która w scenie odkrycia przez Alexandra miniatury domu dokładnie umie wytłumaczyć bohaterowi intencje Malca ${ }^{92}$. W tym miejscu warto też wspomnieć o jeszcze jednym bohaterze Ofiarowania, który wspólnie z chłopcem buduje ową miniaturę jako prezent urodzinowy dla Alexandra. Mowa o listonoszu Otto, który wymyka się jednoznacznemu umieszczeniu go na spektrum. Rafał Rutkowski z wahaniem zalicza go do

${ }^{92}$ Nie znaczy to oczywiście, że Malec pozostaje obojętny bohaterom będącym daleko od ideału. Kiedy w czasie urodzin Alexandra chłopiec znika i nikt nie wie, gdzie się podział, Adelajda martwi się o niego. Jednak po telewizyjnym ogłoszeniu przynoszącym wieści o możliwej apokalipsie, bohaterka wpada w histerię. Chce budzić Malca, mieć go przy sobie. Julia z płaczem błaga ja, aby nie straszyła chłopca, dla którego lepiej będzie, jeśli o niczym się nie dowie. Adelajda myśli w pierwszej kolejności o sobie, natomiast Julia troszczy się przede wszystkim o dziecko. 
grupy postaci, które własnym wysiłkiem osiąnęły „duchowe dziecięctwo”. Jednak stosunek Otta do tego, co niesamowite i niewiarygodne jest znacząco odmienny od podejścia Stalkera, Domenica czy Alexandra. Listonosz w wolnym czasie kolekcjonuje zdarzenia, które uchodzą za niewytłumaczalne, zbiera materiał dowodowy, aby móc z całą pewnością udowodnić ich prawdziwość. Uwydatnia się tutaj jego niska gotowość do przyjęcia tego, co niewiarygodne - potrzebuje dowodów, aby uwierzyć. Z drugiej strony, to bohater niewatpliwie zorientowany we wszelkich sferach zwiąanych z mistyka: to właśnie on informuje Alexandra o cudownych zdolnościach Marii, którą nazywa czarownica. Otto ma tę wiedzę (można dywagować - prawdziwą czy nie), ale sam nie robi z niej użytku, nie podejmuje samodzielnie próby ocalenia świata od katastrofy, lecz jedynie pomaga w tym Alexandrowi. Czy nie starcza mu wiary, czy może pokłada wszelkie nadzieje w przyjacielu - trudno stwierdzić wobec tak zagadkowej postaci.

Poprzez wprowadzenie Otta i Marii do Ofiarowania Tarkowski wyraźnie wykracza poza ramy chrześcijańskiego postrzegania świata. Alexander odwołuje się jednocześnie do Boga i do tajemnych mocy, którymi rzekomo dysponuje „czarownica” Maria. Kiedy następnego ranka świat nadal istnieje, bohater jest pełen wdzięczności za cud, który nastapił. Dziękuje Bogu, wypełniając obietnicę i podpalając dom. Podczas pożaru podbiega zaś do Marii i pada przed nią na kolana. Czepia się nadziei ze wszystkich stron, byle tylko uwolnić się od tego „,́smiertelnego, dławiącego, zwierzęcego strachu”, byle tylko „wszystko było tak jak dawniej, jak dziś rano, jak wczoraj”. W swoim ostatnim filmie Tarkowski pokazuje, że ideał, o którym wciąż opowiada, istnieje niezależnie od religijnych systemów i ponad kulturowymi podziałami, gdyż dotyczy tego, co dla wszystkich ludzi jest uniwersalne - strachu przed śmiercią i pustka, w obliczu których tylko wiara może dać nadzieję.

W zakończeniu Ofiarowania obecny jest wielki akt wiary samego Tarkowskiego. Świadom własnej śmiertelnej choroby, dedykuje film synowi „z nadzieją i ufnością". Jak pod mikroskopem można tu dostrzec kluczową dla całej twórczości reżysera kondycję człowieka: jego czas jest ograniczony, więc tylko wiara $\mathrm{w}$ istnienie czegoś więcej ponad życie doczesne wypełnia jego istnienie sensem. Religijność Tarkowskiego jest właściwie pochodną jego głębokiego humanizmu, a wiara i ufność - czy też szerzej postawa zgodna z ideałem dziecka - rozwiązaniem dla palącego egzystencjalnego problemu człowieka i całej ludzkości. Świat Tarkowskiego można sobie wyobrazić bez Boga, ale nigdy bez wiary. 


\section{BIBLIOGRAFIA}

Alexander-Garrett L., Andrei Tarkovsky: The Collector of Dreams, tłum. M. Amadei Ashot, London 2013.

Birzache A.G., The Holy Fool in European Cinema, Abingdon 2016.

Encyklopedia PWN, hasło: Nikołaj Burlajew, <https://encyklopedia.pwn.pl/haslo/Burlajew-Nikolaj-P;3882140.html> [dostęp: 12.09.2019].

Green P., Andrei Tarkovsky: The Winding Quest, London 1993.

Johnson V.T., Graham P., The Films of Andrei Tarkovsky. A Visual Fugue, Bloomington 1994.

Kaczmarski J., Rublow, <https://www.kaczmarski.art.pl/tworczosc/wiersze/rublow/> [dostęp: 15.09.2019].

Kuśmierczyk S., Księga filmów Andrieja Tarkowskiego, Warszawa 2012.

Le Fanu M., The Cinema of Andrei Tarkovsky, BFI, London 1987.

Martin S., Andrei Tarkovsky, Harpenden 2011.

Pierwszy List do Koryntian. Rozdziat 4, <https://biblia.deon.pl/rozdzial.php?id=289> [dostęp: 13.09.2019].

Robinson J.M., The Sacred Cinema of Andrei Tarkovsky, Maidstone 2006.

Rutkowski R., Stańcie się jak dzieci! O twórczości filmowej Andrieja Tarkowskiego, „Znak” 2007, nr 621, <http://www.miesiecznik.znak.com.pl/6212007rafal-rutkowskistancie-sie-jak-dzieci-o-tworczosci-filmowej-andrieja-tarkowskiego/> [dostęp: 11.09.2019].

Sartre J.-P., Discussion on the Criticism of „Ivan's Childhood”, <http://nostalghia.com/ TheTopics/Sartre.html>, tłum. M.G. Singh [dostęp: 8.09.2019].

Sartre J.-P., Lettera su „L'Infanzia d'Ivan”, „L'Unità”, 9 X 1962, <https://archivio.unita. news/assets/main/1962/10/09/page_006.pdf> [dostęp: 8.09.2019].

Stownik języka polskiego PWN, hasło: jurodiwyj, <https://sjp.pwn.pl/slowniki/jurodiwyj. html> [dostęp: 13.09.2019].

Strefa filmu. Kino Andrieja Tarkowskiego, red. I.A. NDiaye, M. Sokołowski, Toruń 2013.

Tarkovsky. Films, Stills, Polaroids \& Writings, ed. A.A. Tarkovsky, H.J. Schlegel, L. Schirmer, London 2019.

Tarkowski A., Czas utrwalony, przekład, przypisy i posłowie S. Kuśmierczyk, Warszawa 2007.

Tarkowski A., Kompleks Totstoja. Myśli o życiu, sztuce i filmie, wybrał, opracował i przedmową opatrzył S. Kuśmierczyk, Warszawa 1989.

Turovskaya M., Tarkovsky. Cinema as Poetry, tłum. N. Ward, oprac. i wstęp napisał I. Christie, London 1989.

Zwierciadto. Andriej Tarkowski w rozmowie z Jerzym Illgiem i Leonardem Neugerem, oprac. J. Illg, L. Neuger, Kraków 2016. 


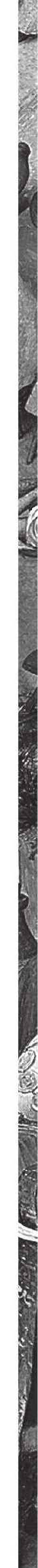


